\title{
Assessing Aquifer Stress Index (ASI) Using Rating Method and Analytic Hierarchy Process for a Coastal Unconfined Aquifer
}

\author{
Nara Somaratne ${ }^{1}$ \\ ${ }^{1}$ South Australian Water Corporation, Victoria Square, Adelaide, Australia \\ Correspondence: Nara Somaratne, South Australian Water Corporation, 250 Victoria Square, Adelaide, SA 5000, \\ Australia. Tel: 618-7424-2379. E-mail: nara.somaratnef@sawater.com.au
}

Received: January 10, 2019

Accepted: January 29, 2019

Online Published: January 31, 2019

doi:10.5539/enrr.v9n1p35

URL: https://doi.org/10.5539/enrr.v9n1p35

\begin{abstract}
Small groundwater basins are highly vulnerable to over draft and susceptible to droughts as they are locally recharged. The sustainable development and management of groundwater basins therefore benefits from quantitative assessment of the basin status in terms of the current stress level. This paper introduces the Aquifer Stress Index (ASI) using a rating method and Analytic Hierarchy Process (AHP), a widely used multi-criteria decision support technique. Six evaluation criteria were used to determine the ASI; water levels, water quality, groundwater pumping, saline water intrusion, recharge and land use threat. For each criterion, a rating score and weight are used to evaluate the stress level. Rating scores for criteria were assigned based on multiple datasets obtained from the field investigations. Weightings for criteria were determined by pairwise comparison of AHP process. Based on the ASI, five characteristic stress regimes of the aquifers are defined: no stress, low stress, moderate stress, high stress and extreme stress. The stress level indicates the extent of groundwater availability and current development impact on the aquifer integrity. The method was applied in detail to Uley South coastal aquifer, and results indicate that the overall stress level of the aquifer is moderate. This research indicates that declining water levels are the major cause of Uley South basin's aquifer stress, due to ongoing extractions and reduced long-term recharge. Depending on the aquifer stress level, management plans can be developed for sustainable use of the aquifer to help ensure current and future water security.
\end{abstract}

Keywords: Aquifer Stress Index, Groundwater Pumping, Saline Intrusion, Recharge, Water Level Decline, Land Use Threat, Water Quality Decline, Sustainable Allocation

\section{Introduction}

Climate change is considered one of the main driving forces of declining water availability (Ashraf, 2017). When groundwater storage is closely tied to annual recharge, reduction of recharge will cause stress on available water resources. This is particularly dominant in small groundwater basins that depend on local rainfall-derived recharge. Assessing the stress on groundwater resources is crucial to inform science-based policy and management, yet water stress assessments have often been neglected (Gleeson \& Wada, 2013). In some arid and semi-arid regions, groundwater is the only available resource, and hence is a critical resource for agricultural production; sustainable ecosystem functions, drinking water and industrial water supply. Therefore, understanding the amount of groundwater used versus the volume available is crucial to evaluate future water availability (Sun et al., 2008; Richey et al., 2015; Eldardiry et al., 2016). The growth of demand place groundwater resources under increasing stress, leading to persistent over extraction (Vaux, 2011). In order to identify stressed aquifers, Gleeson et al. (2012) introduced the groundwater footprint as an index displaying the intensity of groundwater usage of large aquifer systems worldwide, making assessment of groundwater stress consistently across a nation (Gleeson \& Wada, 2013). The groundwater footprint was defined as the area-averaged annual abstraction of groundwater divided by the recharge rate minus the groundwater contribution to environmental streamflow (Gleeson et al., 2012). Following Gleeson et al. (2012), Ahner (undated) redefined the groundwater stress index as the withdrawal (or use of groundwater) minus returns flow; divided by groundwater recharge minus groundwater contributing to environmental flow.

The need for a precautionary approach to water allocation between societal and ecological systems for sustainability has been recognized (Zhou et al., 2015). This requires allocating water across competing demands, and balancing the financial and social resources required supporting necessary water systems (Russo et al., 2014). 
There are many definition and evaluation techniques of 'sustainability' (Kalf \& Wooley, 2005). In order to address the ambiguity of various definitions of "sustainability", Hashimoto et al. (1982) developed the Reliability, Resilience and Vulnerability (RRV) methodology for sustainability analysis. A number of other indicators of groundwater sustainability, vulnerability and stress have also been proposed (Gleeson et al., 2012; Web et al., 2007; Pandey et al., 2011; Castagna et al., 2015; Senet-Aparicio et al., 2015). Indicators include the groundwater quantity and quality indicators developed by Web et al. (2007), as well as the water use regime, the social sustainable aquifer yield (Molina et al., 2018), the groundwater sustainability infrastructure index (Pandey et al., 2011) and the groundwater footprint (Gleeson et al., 2012). Groundwater stress can be assessed at multiple scales using the groundwater footprint methodology that has been applied globally but only for large aquifers (Gleeson et al., 2012). In their work, Gleeson et al. (2012) defined four characteristic stress regimes: Overstressed, Variable Stress, Human-dominated Stress, and Unstressed. According to Kundzewicz (2009), availability of water in adequate quantity and quality is a necessary condition for sustainable development. Hunter et al. (2015) introduced a multivariate, dynamic sustainability evaluation technique and corresponding performance indicator called Measure of Sustainability (MoS) for resource management that is more adapted to withstand future parameter variation.

Undoubtedly, groundwater indicators are useful, but assessments should also include monitoring and data-based assessment to provide quantitative information about the current status and likely future trends in the groundwater system. Indicators are, however, useful instruments for communicating key information about systems to policy makers and the general public (Vrba \& Lipponen, 2007) that allow for comparison across different regions and different aspects of water management (Wang \& Wu, 2006). The safe (sustainable) exploitation of groundwater causes no negative effects on the natural and ecological environment in the short or longer term. The safety status warning refers to providing information on the maximum exploitation that can take place without causing any nonrecoverable negative impacts (Zou, 1999).

While the groundwater stress index is useful for adopting broader management goals at regional or national scales, the groundwater index defined above is less useful for managing small groundwater basins that are recharged locally and requires integrated adaptive management. This is because the groundwater stress index lacks important measures of sustainability, including falling watertable, drying wetlands, increasing seawater intrusion, land use threats and general deterioration of water quality. Thus, a decision support system is needed which takes all identified criteria of relevance into account when choosing between most influential factors that cause stress affecting sustainability.

Multi-criteria decision making (MCDM) - a well-known decision making process, in conjunction with Analytic Hierarchy Process (AHP) is widely used in variety of fields. A few relevant recent works are provided below. Agarwal et al. (2003) computed groundwater potential index (GWPI) by the weighted linear combination method using analytical network process (ANP) and AHP. AHP and ANP are used to determine the weights of various themes and their classes for identifying the groundwater potential zone. The ecohydrological study of Al Zubi (2009) incorporates the use of ecosystem properties as a management tool in water resource management. Zhang et al. (2013) used the AHP approach to determine the weight indices of different factors that impact wetland ecosystems. Similarly, Tirkey et al. (2013) demonstrated the use of AHP-GIS based DRASTIC model (Aller et al., 1987) to estimate the relative probability of contamination of the groundwater resources. The study of Xi \& Poh (2014) employed System Dynamics (SD) and AHP to alleviate the risks of urban flooding and diversify sources of water supply. In a different way of problem formulation, White et al. (2016) framed groundwater management as a system control problem. Each component was weighted based upon proposed relative importance. Shabbir \& Ahmed (2016) presented the analysis of the vulnerability status of the water resource with the help of AHP. The vulnerability index developed as a combination of climatic and socio-economic factors selected on the basis of their significance, relevance and scientific credibility. Kumar \& Krishna (2016) used geospatial technology and AHP for delineating groundwater potential zones. Recently, Wijitkosum (2018) applied the Fuzzy Analytic Hierarchy Process (FAHP) method to evaluate the risk of agricultural drought considering five risk factors divided into fifteen criteria. These criteria determine the weight and score used to evaluate their parental risk factors. Liu et al. (2017) used the Fuzzy Comprehensive Evaluation Model (FCE) for the evaluation in its role to assess water stress. The index system of Liu et al. (2017) for water stress assessment included four aspects; water supply and demand balance, socio-economy, agricultural production and the ecological environment. Cambrainha \& Fontana (2018) were able to make the balance of water supply-demand strategies through selecting alternatives for both supply and demand. Huang et al. (2018) modified DRASTIC model that combined factors of intrinsic aquifer vulnerability and land use was applied to assess groundwater vulnerability. The weights of parameters were adjusted by using the AHP to optimize the model. 
The objective of this study is to introduce an Aquifer Stress Index (ASI) to assess the impact of the current level of development on the aquifer. Six assessment criteria are used: water levels, water quality, groundwater pumping, saline water intrusion, declining long-term recharge and land use threat. Each criterion is divided into five categories and ratings were assigned according to the current status of the criteria. The range of ratings is derived from the DRASTIC model (Aller et al., 1987). Weighting for each criterion are derived by pairwise comparison using AHP. Based on the ASI, the aquifer is classified into: no stress, low stress, moderate stress, high stress and extreme stress. Once the stress level of the aquifer is known, appropriate management practices can be implemented.

\section{Geology and Hydrogeology of the Study Site}

A complete description of the geology and hydrogeology of the Uley South basin is provided by Somaratne et al. (2018). For reader convenience and completeness of this paper, the detail from Somaratne et al. (2018) is reproduced.

Groundwater provides $77 \%$ of the Eyre Peninsula (EP) water supply system from Southern basins (Uley South, Coffin Bay, Uley Wanilla, Uley East and Lincoln Basin) (Figure 1a). Of these groundwater supplies, the Uley South basin is the largest and, regionally, most strategic. The Uley South basin is approximately $113 \mathrm{~km}^{2}$ in area and is located on the Southern EP of South Australia (Figure 1a). The region has a semi-arid climate, which is characterized by winter-dominant (June-August) rainfall and hot, dry summer (December-February) (Harrington et al., 2006). Long-term average annual rainfall is $550 \mathrm{~mm}$ and average annual pan evaporation is $1550 \mathrm{~mm}$. There is no well-developed soil horizon and the surface is composed mainly of skeletal soils $(<30 \mathrm{~cm})$ : sandy or clayey loam, overlying calcrete (Evans, 1997). The low lying central part of the basin contains numerous sinkholes. Runoff is highly ephemeral, occurring only after moderate to high intensity rainfall and persisting only tens to hundreds of meters before entering a vast array of epikarsts and sinkholes. A survey of a $4 \mathrm{~km}^{2}$ area found a density of about one sinkhole per $0.07 \mathrm{~km}^{2}$ with approximate size ranging from $0.4 \mathrm{~m}$ to $2.5 \mathrm{~m}$ diameter (Somaratne, 2014).
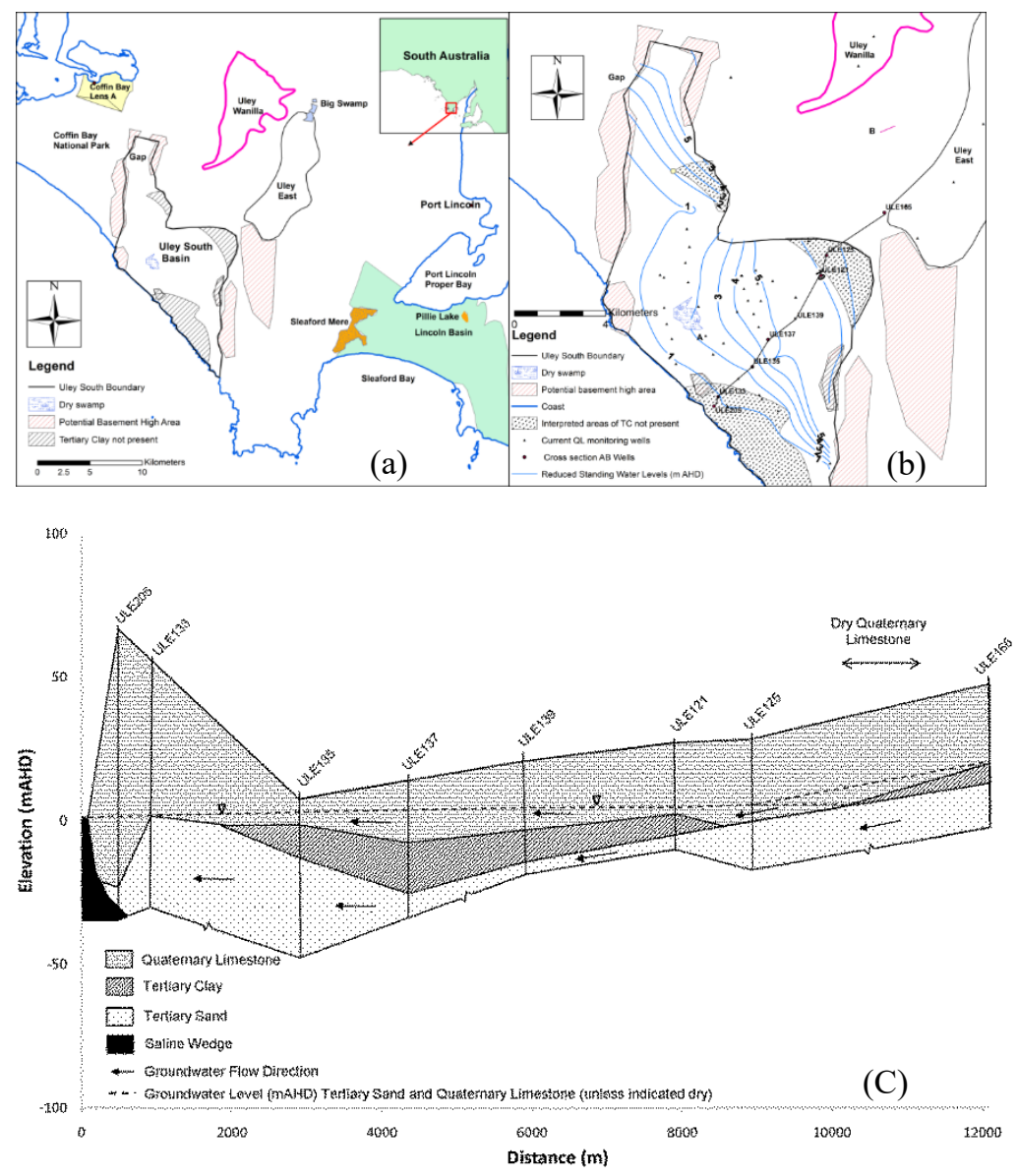

Figure 1. (a) Uley South basin with Coffin Bay Lens A, Uley Wanilla, Uley East, and Lincoln Basins (Somaratne et al., 2018) (b) Groundwater elevation contours (Somaratne et al., 2018) (c) Cross section AB

(Somaratne et al., 2018) 
The morphology of the basin is associated with ancient dune systems overlying basement ridges and troughs, with distinct dunal landforms and subtle undulations defining local surface drainage systems (Harrington et al., 2006). The hydrogeology of Uley South basin comprises Quaternary Limestone (QL) of an average thickness of 15-30m, underlain by a Tertiary Clay (TC) unit of $5-25 \mathrm{~m}$ thickness, and a Tertiary Sand (TS) aquifer. The QL aquifer is highly heterogeneous, typical of karstic aquifers. From pump testing carried out on production wells at 22 locations, hydraulic conductivity of the QL aquifer is found in the range of $131-2196 \mathrm{~m}^{-1} \mathrm{~d}^{-1}$, and specific yield range from 0.03-0.72. The TC is discontinuous and, where present, forms an aquitard between the TS and the QL aquifer systems. Uley South basin may be linked to the adjacent Coffin Bay aquifer through the basement low area (Gap in Figure 1a) in the north-western boundary. Groundwater flow direction is from north-east to south-west towards the coast (Figure 1b). The basement high area between Coffin Bay and Uley South restricts groundwater movement to the west, except potential basement low area of 700m (Gap in Figure 1a) (Somaratne, 2015a). Uley South QL aquifer receives recharge from three sources; diffuse recharge, point recharge from sinkholes and continuous leakage of TS water from the northern boundary where TC is absent (Somaratne, 2015b) (Figure 1c). During intense rain events, runoff from neighboring limestone dry areas and basement high areas drains to karstic features in Uley South that recharge the aquifer (ibid). The basin is topographically closed and bounded by coastline and sand dunes to the west; and inland to the north and east by topographic rises of dry limestone.

\section{Materials and Methods}

\subsection{Problem Formulation and Evaluation of Ratings}

Aquifer stress index (ASI) is evaluated using six criteria (Table 1) that can influence the stress on the aquifer. Each of the six criteria (water level, water quality, groundwater pumping, saline water intrusion, recharge and land use) are rated according to the current state of the aquifer. Influence of each criterion on aquifer stress can be summarized as:

water levels (WL): Falling water levels in the aquifer is a sign of stress. This needs to be evaluated given the impact of water level buffering in coastal aquifers; and stable or rising water levels in dryland salinity catchment taking into consideration.

water quality (WQ): Deteriorating water quality is a sign of a stressed aquifer. The most common water quality parameter is salinity but other parameters, such as nitrate level in agricultural catchment can also be used.

groundwater pumping $(\mathrm{P})$ : The most obvious and reported criteria is the large drawdowns caused by excessive pumping beyond the sustainability level of the aquifer.

Table 1. Evaluation criteria and ratings

\begin{tabular}{|c|c|c|c|c|c|}
\hline Criteria & Category 1 & Category 2 & Category 3 & Category 4 & Category 5 \\
\hline $\begin{array}{l}\text { Falling water } \\
\text { levels (WL) }\end{array}$ & $\begin{array}{l}\text { Stable-no } \\
\text { decline }\end{array}$ & $\begin{array}{l}\text { Short term decline } \\
(0-5 \%) \text { and recovery }\end{array}$ & $\begin{array}{l}\text { Medium term decline } \\
(5-10 \%) \text { and some } \\
\text { recovery }\end{array}$ & $\begin{array}{l}\text { Long-term decline } \\
(10-20 \% \text { )and no } \\
\text { recovery }\end{array}$ & $\begin{array}{l}\text { Long-term continuous } \\
\text { decline, }>20 \%\end{array}$ \\
\hline $\begin{array}{l}\text { Deteriorating } \\
\text { water quality } \\
\text { (WQ) }\end{array}$ & Natural quality & $\begin{array}{l}\text { Assumed to have } \\
\text { some degradation }\end{array}$ & $\begin{array}{l}\text { Can be used with } \\
\text { blending }\end{array}$ & $\begin{array}{l}\text { Not suitable without } \\
\text { treatment }\end{array}$ & $\begin{array}{l}\text { Water quality is } \\
\text { impaired }\end{array}$ \\
\hline $\begin{array}{l}\text { Excessive } \\
\text { pumping }(\mathrm{P})\end{array}$ & $\begin{array}{l}\text { Less than } 30 \% \\
\text { of long-term } \\
\text { recharge }\end{array}$ & $\begin{array}{l}30-40 \% \text { of long-term } \\
\text { recharge }\end{array}$ & $\begin{array}{l}40-50 \% \text { of long-term } \\
\text { recharge }\end{array}$ & $\begin{array}{l}50-60 \% \text { of long-term } \\
\text { recharge }\end{array}$ & $\begin{array}{l}>70 \% \text { of long-term } \\
\text { recharge }\end{array}$ \\
\hline $\begin{array}{l}\text { Saline water } \\
\text { intrusion (SWI) }\end{array}$ & $\begin{array}{l}\text { Under natural } \\
\text { condition }\end{array}$ & $\begin{array}{l}\text { Slight encroachment } \\
\text { but long-term stable }\end{array}$ & $\begin{array}{l}\text { Moderate } \\
\text { encroachment } \\
\text { affecting some water } \\
\text { users }\end{array}$ & $\begin{array}{l}\text { Continuous } \\
\text { encroachment } \\
\text { requiring long-term } \\
\text { management } \\
\text { /intervention }\end{array}$ & $\begin{array}{l}\text { Continuously } \\
\text { encroaching } \\
\text { impairing water } \\
\text { quality beyond } \\
\text { intended use }\end{array}$ \\
\hline $\begin{array}{l}\text { Declining } \\
\text { recharge }{ }^{\circledR}\end{array}$ & $\begin{array}{l}\text { Long-term } \\
\text { stable recharge } \\
\text { with seasonal } \\
\text { fluctuation }\end{array}$ & $\begin{array}{l}\text { Slightly declining } \\
\text { long-term recharge } \\
\text { with }<5 \text { year } \\
\text { recovery period }\end{array}$ & $\begin{array}{l}\text { Moderately declining } \\
\text { long-term recharge } \\
\text { with } 5 \text {-10 year } \\
\text { recovery period }\end{array}$ & $\begin{array}{l}\text { Moderately declining } \\
\text { long-term recharge } \\
\text { with no recovery }\end{array}$ & $\begin{array}{l}\text { Continuously rapid } \\
\text { declining long-term } \\
\text { recharge }\end{array}$ \\
\hline $\begin{array}{l}\text { Land use threat } \\
\text { (LU) }\end{array}$ & $\begin{array}{l}\text { Protected water } \\
\text { reserve }\end{array}$ & Rangeland & Agricultural land & $\begin{array}{l}\text { Agricultural land with } \\
\text { developments }\end{array}$ & Urban or built-up \\
\hline Ratings & 1 & 3 & 5 & 8 & 10 \\
\hline
\end{tabular}


salt water intrusion (SWI): In coastal aquifers, excessive pumping and lowering of water level causes sea water intrusion along the coastline. However, salt water can be moved to aquifer through other mechanisms such as upconning, inter-aquifer exchange and poor quality water movement into the aquifer from surrounding areas.

recharge $(\mathrm{R})$ : Declining recharge is one of the main causes of aquifer stress. This could be due to natural climate change impact or man-made impact, such as afforestation in recharge zone. The method of recharge estimation should be carefully selected, as the chloride mass balance and other tracer based method provide long-term recharge rather than annual estimate.

land use threat (LU): Land use changes such as intensification of agricultural activities or converting agricultural lands into urban environment can cause both a reduction in recharge as well as threaten on water quality.

Weight multipliers are derived using AHP process. The final ASI is computed similar to the DRASTIC Index (Aller et al., 1987), giving ASI as the weighted sum of the six criteria using the following equation:

$$
A S I=W_{\mathrm{r}} \times W L_{w}+W_{\mathrm{r}} \times W Q_{w}+P_{r} \times P_{w}+S W I_{r} \times S W I_{w}+R_{r} \times R_{w}+L_{r} \times L_{w}
$$

where parameters ' $r$ ' and ' $w$ ' are the ratings (Table 1) and weights assigned to each criterion.

Based on ASI, aquifer is classified into five levels as: $1=$ No stress; $1-3=$ Low stress, $3-5=$ Moderate stress; 5-8=High stress; and $8-10=$ Extreme stress.

\subsection{The Analytic Hierarchy Process and Pairwise Comparison for Determination of Criteria Weightings}

The AHP introduced by Saaty $(1977,1980)$ is a systematic procedure for dealing with complex decision-making problems in which many competing alternatives exist. AHP uses a multi-level hierarchical structuring of the elements; objectives, criteria, sub-criteria and alternatives that are involved in a decision problem (Triantaphyllou, 1997). As the hierarchy incorporates the knowledge, the experience and the intuition of the decision-makers for the specific problem, AHP may be the most appropriate technique for groundwater allocation decision making. Typically, water management problems cover a wide range of technical, economic, environmental and social issues, and concern groups with diverse interests in resource management (Anagnostopoulos et al., 2005). The hierarchy evaluation is based on pairwise comparisons. One of the most prominent features of AHP methodology is to evaluate quantitative as well as qualitative criteria and alternatives on the same preference scale (Franek \& Kresta, 2014). The fundamental scale with an explanation of the absolute numbers is given in Table 2.

The comparisons can be derived from real measurements or a grading scale reflecting decision-maker's preferences. The preferences are determined with relative grades expressed as numerical values, usually 1-9, where 1 indicates that the compared criteria are equivalent and 9 indicates that the first of the compared elements is strongly preferred with respect to the other element (Saaty, 1980).

Table 2. The fundamental scale of absolute numbers (Saaty, 1980)

\begin{tabular}{lll}
\hline $\begin{array}{l}\text { Intensity of } \\
\text { Importance }\end{array}$ & Definition & Explanation \\
\hline 1 & $\begin{array}{l}\text { Equal importance } \\
\text { Weak importance } \\
2\end{array}$ & Two activities contribute equally to the objective \\
3 & $\begin{array}{l}\text { Moderate importance } \\
\text { Moderate plus }\end{array}$ & Experience and judgement slightly favour one activity over another \\
5 & $\begin{array}{l}\text { Strong importance } \\
\text { Strong plus }\end{array}$ & Experience and judgement strongly favour one activity over another \\
7 & $\begin{array}{l}\text { Very strong or demonstrated } \\
\text { importance }\end{array}$ & $\begin{array}{l}\text { An activity is favoured very strongly over another; its dominance } \\
\text { demonstrated in practice }\end{array}$ \\
9 & Very, very strong & The evidence favouring one activity over another is of the highest possible \\
\hline
\end{tabular}

Thus for $n$ decision criteria, $n(n-1) / 2$ number of comparisons are made and results in generating $n \times n$ matrix given in Equation (2) with properties given by Equations (3) and (4).

$$
\mathbf{A}=\left[\begin{array}{cccc}
a_{11} & a_{12} & . . & a_{1 n} \\
a_{21} & a_{22} & . . & a_{2 n} \\
. \cdot & \cdot . & . . & . \cdot \\
a_{n 1} & a_{n 2} & . . & a_{n n}
\end{array}\right]
$$


The matrix A with elements $\mathrm{a}_{\mathrm{ij}}$ has the following properties:

$$
\begin{gathered}
a_{i j}=1, \text { when } i=j ; i, j=1,2,3 \ldots . n \\
\text { if } a_{i j}=\alpha, \text { then } a_{j i}=\frac{1}{\alpha} ; i, j=1,2,3 \ldots . n
\end{gathered}
$$

Once the values are defined, a comparison matrix is normalized and the local priority (the relative dominance) of the matrix elements with respect to the higher level criterion is calculated. The overall priority of the current level elements is calculated by adding the products of their local priorities by the priority of the corresponding criterion of the immediately higher level. Next, the overall priority of a current level element is used to calculate the local priorities of the immediate lower level, which can be used as a criterion, till the lowest level of the hierarchy is reached. The priorities of the lowest level elements (alternatives) provide the relative contribution of the elements in achieving the overall goal (Anagnostopoulos et al., 2005).

The values of the normalized matrix, $\boldsymbol{B}$, are determined based on Equation (5) and priority vectors indicating weights of elements from Equation (6) (Blachoski, 2015):

$$
\begin{gathered}
b_{\mathrm{ij}}=\frac{a_{i j}}{\sum_{i=1}^{n} a_{i j}} \\
\mathrm{w}_{i}=\frac{\sum_{j=1}^{n} b_{i j}}{n}
\end{gathered}
$$

Where $\left\{w_{i}\right\}$ is the priority weight vector.

The consistency measure is expressed as a vector, and given in Equation (7). This is done by adding the columns in judgment matrix, $\boldsymbol{A}$, and multiplying the resulting vector by the priority vector, which is the approximated eigenvector. This yields an approximation of the maximum eigenvalue. Thereafter, the consistency index (CI) value is calculated by using the Equation (7). Averaging the value of consistency vector, Eigen value, $\lambda$ is calculated from (8). Next the consistency ratio (CR) is obtained by dividing the CI value by the Random Consistency Index (RI) given in Table 3.

$$
\begin{gathered}
c_{i}=\frac{1}{w_{i}} \sum_{j=1}^{n} w_{j} a_{i j} \\
\lambda=\frac{\sum_{j=1}^{n} c_{j}}{n}
\end{gathered}
$$

Consistency index (CI) is (Saaty, 1980):

$$
\mathrm{CI}=\frac{\lambda-n}{n-1}
$$

Consistency ratio (CR) is (Saaty, 1980):

$$
\mathrm{CR}=\frac{\mathrm{CI}}{\mathrm{RI}}
$$

The RI is depends on the number of compared elements.

Table 3. RI values for different values of $n$ (Saaty, 1980)

\begin{tabular}{llllllllll}
\hline$n$ & 1 & 2 & 3 & 4 & 5 & 6 & 7 & 8 & 9 \\
\hline RI & 0 & 0 & 0.58 & 0.90 & 1.12 & 1.24 & 1.32 & 1.41 & 1.45 \\
\hline
\end{tabular}

In AHP the pairwise comparisons in a judgment matrix are considered to be adequately consistent if the corresponding CR is less than 10\% (Saaty, 1980). If the CR value is greater than 0.10 , then it is suggested to study the problem further and re-evaluate the pairwise comparisons (Triantaphyllou \& Mann, 1995). Each of the selected criteria has a predetermined, fixed and relative weight that reflects its relative importance to cause aquifer stress. The most significant factors have a higher weight and vice-versa. The comparison matrix generated by the author's 
expertise in Uley South basin using Saaty's scale (Saaty, 1980) is shown below in Table 4. The normalized matrix, and calculation of the consistency index together with consistency ratio is given in Table 5 .

Table 4. Pairwise Comparison matrix for calculation of weights

\begin{tabular}{|c|c|c|c|c|c|c|}
\hline Criteria & WL & WQ & $\mathrm{P}$ & SWI & $\mathrm{R}$ & LU \\
\hline WL & 1 & 1 & 3 & 3 & 7 & 7 \\
\hline WQ & 1 & 1 & 3 & 1 & 7 & 7 \\
\hline $\mathrm{P}$ & $1 / 3$ & $1 / 3$ & 1 & $1 / 3$ & 3 & 7 \\
\hline SWI & $1 / 3$ & 1 & 3 & 1 & 7 & 7 \\
\hline $\mathrm{R}$ & $1 / 7$ & $1 / 7$ & $1 / 3$ & $1 / 3$ & 1 & 3 \\
\hline LU & $1 / 7$ & $1 / 7$ & $1 / 7$ & $1 / 7$ & $1 / 3$ & 1 \\
\hline Sum & 2.9523 & 3.6190 & 10.4761 & 5.8095 & 25.3333 & 32 \\
\hline
\end{tabular}

Table 5. Normalized matrix, consistency index and consistency ratio

\begin{tabular}{|c|c|c|c|c|c|c|c|c|c|}
\hline Criteria & WL & WQ & $\mathrm{P}$ & SWI & $\mathrm{R}$ & $\mathrm{LU}$ & Total & Normalized Vector & Consistency measure \\
\hline $\mathrm{WL}$ & 0.33871 & 0.27631 & 0.28636 & 0.51639 & 0.27631 & 0.21875 & 1.91 & 0.3188 & 6.78 \\
\hline WQ & 0.33871 & 0.27631 & 0.28636 & 0.17213 & 0.27631 & 0.21875 & 1.57 & 0.2614 & 6.55 \\
\hline $\mathrm{P}$ & 0.11290 & 0.09210 & 0.09545 & 0.05737 & 0.11842 & 0.21875 & 0.70 & 0.1158 & 6.37 \\
\hline SWI & 0.11290 & 0.27631 & 0.28636 & 0.17213 & 0.27631 & 0.21875 & 1.34 & 0.2238 & 6.70 \\
\hline $\mathrm{R}$ & 0.04838 & 0.03947 & 0.03181 & 0.05737 & 0.03947 & 0.09375 & 0.31 & 0.0517 & 6.44 \\
\hline LU & 0.04838 & 0.03947 & 0.01363 & 0.02459 & 0.01315 & 0.09375 & 0.17 & 0.0284 & 6.23 \\
\hline Sum & 1 & 1 & 1 & 1 & 1 & 1 & 6 & CI & 0.102323 \\
\hline \multirow{2}{*}{\multicolumn{8}{|c|}{ Note: Normalized vector is the criteria weighting }} & RI & 1.24 \\
\hline & & & & & & & & $\mathrm{CR}$ & $0.08<0.1$ \\
\hline
\end{tabular}

\subsection{Salinity Measurements and Recharge Estimation}

Salinity measurements were undertaken to study the extent of salinization. Vertical profiles of monitoring and production wells were obtained using YSI 600XLM Sonde (YSI incorporated, 2014) connected to a laptop computer. The sonde was calibrated using conductivity standard placed in a pre-rinsed and dry calibration cup, with the probe end of the sonde immersed into the solution and calibrated according to the procedure in the manual. The sonde was connected to a $120 \mathrm{~m}$ length cable and lowered down the well from surface to the well base, recording electrical conductivity (EC) data along the way. The calibrated 600 XLM Sonde has a conductivity range of $0-100,000 \mu \mathrm{S} . \mathrm{cm}^{-1}$ with accuracy of measurements $\pm 0.5 \%$ reading, and can operate in a temperature range $-5^{\circ} \mathrm{C}$ to $45^{\circ} \mathrm{C}$ up to $200 \mathrm{~m}$ depth (Somaratne \& Ashman, 2018).

The annual recharge rate to the aquifer was assessed using watertable fluctuation (WTF) (Healy \& Cook, 2002) method. The long-term average annual recharge was cross-checked with the previous recharge value obtained from the generalized chloride mass balance (CMB) method (Somaratne, 2015a). The WTF method is based on relating changes in measured watertable elevation with changes in the amount of water in aquifer storage:

$$
\mathrm{R}=\mathrm{S}_{\mathrm{y}} \frac{\Delta \mathrm{h}}{\Delta \mathrm{t}}
$$

where $\mathrm{R}$ is recharge rate, $\mathrm{S}_{y}$ is specific yield (was taken as 0.25 ) and $\Delta \mathrm{h}$ is the peak watertable rise attributed to the recharge at time $\Delta \mathrm{t}$ (Healy \& Cook, 2002).

\subsection{Prediction of Position of the Saline Wedge}

In this study, an analytical solution developed by Strack (1976) for interface problems in coastal aquifers was used for analysis of the position the of saline water wedge. A single governing potential equation has been used by Strack (1976) to solve the problem across two zones of the coastal aquifer (Figure 2). The method simplifies the aquifer and flow system by assuming steady state flow in a homogeneous aquifer where the vertical flow rates can be neglected in relation to horizontal ones (Dupuit-Forchheimer assumption). The interface separates the freshwater from saltwater at rest, and single valued and continuous potential can be defined. Saltwater and freshwater are separated by an interface rather than by a transition zone, and flow rates in the saltwater region are negligible in relation to the flow rates in the freshwater region. Despite simplifying assumptions, analytical 
solutions can be used as a tool for first order analysis prior to application of more sophisticated models (Cheng \& Quazar, 1999). Potential flow theory of Strack (1976) is applied with several assumptions: the sea water-fresh water interface is a sharp interface instead of a variable density transition zone, the sea level is constant, the DupuitForchheimer assumption is applied to neglect the vertical flow, and the Ghyben Herzberg formula is applicable. Saline wedge penetration into the aquifer depends on: aquifer hydraulic conductivity, the square of the aquifer thickness, and inversely on the freshwater flow to the sea (Custodio, 1987).

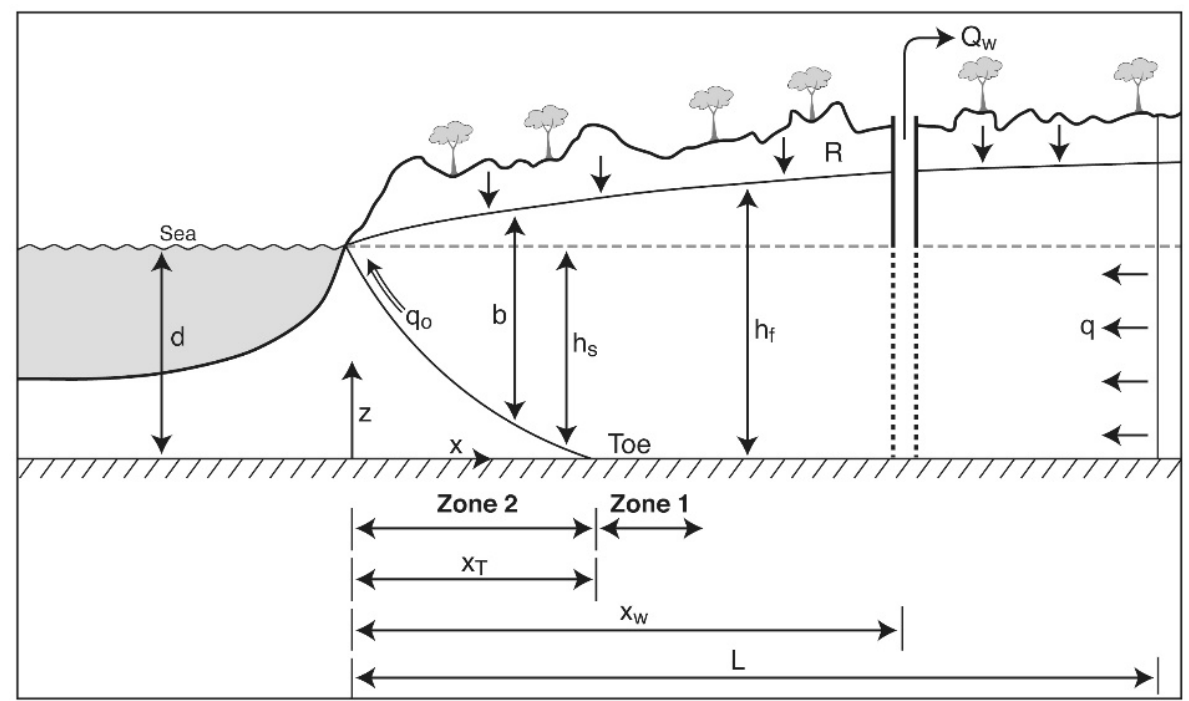

Figure 2. Interface flow in an unconfined aquifer with a pumping well (Somaratne \& Ashman, 2018)

The location of the toe of the saltwater wedge can be computed for the x-y plane using (Felisa et al., 2013; Naderi et al., 2013) for multiple wells:

$$
\phi_{\mathrm{T}}=\frac{\mathrm{q}_{0}}{\mathrm{~K}} \mathrm{x}_{\mathrm{T}}+\sum_{\mathrm{i}=1}^{\mathrm{n}} \frac{\mathrm{Q}_{\mathrm{wi}}}{4 \pi \mathrm{K}} \ln \left[\frac{\left(\mathrm{x}_{\mathrm{T}}-\mathrm{x}_{\mathrm{Wi}}\right)^{2}+\left(\mathrm{y}_{\mathrm{T}}-\mathrm{y}_{\mathrm{wi}}\right)^{2}}{\left(\mathrm{x}_{\mathrm{T}}+\mathrm{x}_{\mathrm{wi}}\right)^{2}+\left(\mathrm{y}_{\mathrm{T}}-\mathrm{y}_{\mathrm{wi}}\right)^{2}}\right]
$$

where $\mathrm{q}_{0}$ is the uniform discharge to the sea per unit width of the aquifer, ' $\mathrm{Q}_{\mathrm{wi}}$ ' is the pumping rate of $\mathrm{i}^{\text {th }}$ well located at coordinates $\left(\mathrm{x}_{\mathrm{wi}}, \mathrm{y}_{\mathrm{wi}}\right)$, and ' $\mathrm{n}$ ' is the number of wells. The equation (12) strictly valid for semi-infinite aquifer dimensions with a single boundary at the coastline (Montoglou, 2003). The $\mathrm{q}_{0}$ is found from equations developed for $\mathrm{h}_{\mathrm{f}}$ as a function of aquifer parameters and distance from the coast, $\mathrm{x}$ (Strack, 1976). For Zone 1 (x $\left.\geq \mathrm{x}_{\mathrm{T}}\right)$ :

$$
\mathrm{h}_{\mathrm{f}}=\sqrt{\frac{2 \mathrm{q}_{0} \mathrm{x}-\mathrm{Rx}^{2}}{\mathrm{~K}}+(1+\delta) d^{2}}-\mathrm{d}
$$

For Zone $2\left(\mathrm{x} \leq \mathrm{x}_{\mathrm{T}}\right)$ :

$$
\mathrm{h}_{\mathrm{f}}=\sqrt{\frac{2 \mathrm{q}_{0} \mathrm{x}-\mathrm{Rx}^{2}}{\mathrm{~K}}\left(\frac{\delta}{(1+\delta)}\right)}
$$

Rearranging equations (13) and (14) yields:

For Zone 1:

$$
\mathrm{q}_{0}=\frac{\mathrm{K}\left(\left(\mathrm{h}_{\mathrm{b}}+\mathrm{d}\right)^{2}-(1+\delta) \mathrm{d}^{2}\right)+\mathrm{R} \mathrm{x}_{\mathrm{b}}^{2}}{2 \mathrm{x}_{\mathrm{b}}}
$$

For Zone 2:

$$
\mathrm{q}_{0}=\left(\frac{1+\delta}{\delta}\right)\left(\frac{\mathrm{K}}{2 \mathrm{x}_{\mathrm{b}}}\right) \mathrm{h}_{\mathrm{b}}^{2}+\frac{\mathrm{Rx}_{\mathrm{b}}}{2}
$$

where $h_{b}$ is the measured head at distance $x_{b}$ from the coast. 


\section{Results and Discussion}

\subsection{History of the Basin Development}

Early investigations focusing on hydrogeology of the QL aquifer was described by Segnit (1942), Johns (1961) and Painter (1969). Using Darcy's law, annual safe yield was estimated at $1.1 \times 10^{6} \mathrm{~m}^{3}$ by Shepherd (1963), Painter (1969) at 3.6-7.3 $\times 10^{6} \mathrm{~m}^{3}$, Morton \& Steel (1968) at $15 \times 10^{6} \mathrm{~m}^{3}$ and Selby (1974) at $1.8 \times 10^{6} \mathrm{~m}^{3}$ (Selby, 1974). Subsequently, Barnett (1978) also applied water balance method to estimate safe yield of the Uley South basin, and yield was estimated at $30 \times 10^{6} \mathrm{~m}^{3}$ with $50 \%$ recommended as the safe yield for withdrawal. As a result of salinization of the Lincoln basin (Somaratne \& Ashman, 2018), the need to develop the Uley South basin for water supply to Eyre Peninsula was considered. In 1976, the basin was brought to production. Figure 3 depict the average annual recharge, annual extraction and long-term observed water levels of the basin. In 1968, the highest annual rainfall, $917 \mathrm{~mm}$, in the last century occurred giving annual recharge of about 500mm (Figure 3). In 1992, the second highest annual rainfall of $873 \mathrm{~mm}$, occurred giving basin annual recharge of $275 \mathrm{~mm}$. In general, the 19611992 period is considered to be high recharge years. During the 1961-1992 (32 years) period, average annual recharge to the basin was $142 \mathrm{~mm}$, well above the long-term value of $122 \mathrm{~mm}$. In the subsequent 25 year period (1993-2017), basin average annual recharge was $98 \mathrm{~mm}$ despite the fact that above average recharge occurred in; 1995-96, 2000-01, 2005, 2009, and 2013-14.

In Uley South basin, it is typical to have 2-3 low recharge years followed by 1-3 high recharge years (Figure 3). During the 1997-1999 drought period, the basin received 84mm annual recharge. In this period, water levels declined by $0.61 \mathrm{~m}$ from 1996 values. The second three year drought period was 2015-2017 with total recharge of $208 \mathrm{~mm}$, and a corresponding decline in water level from 2014 of about $0.4 \mathrm{~m}$. Water level decline during the predevelopment period from 1968 to 1976 was $0.73 \mathrm{~m}$. This is due to natural discharge to the sea. During the 19762017 periods, a total of $226 \times 10^{6} \mathrm{~m}^{3}$ has been extracted from the basin. The basin average annual recharge rate over the 1976-2017 period is $113.5 \mathrm{~mm}$ giving a total recharge of $538 \times 10^{6} \mathrm{~m}^{3}$. Therefore, long term extraction is $42 \%$ of the recharge for the same period. Average water level decline during 1976-2017 periods was $1.39 \mathrm{~m}$. Longterm average annual recharge from 1961-2017 is $122 \mathrm{~mm}$.

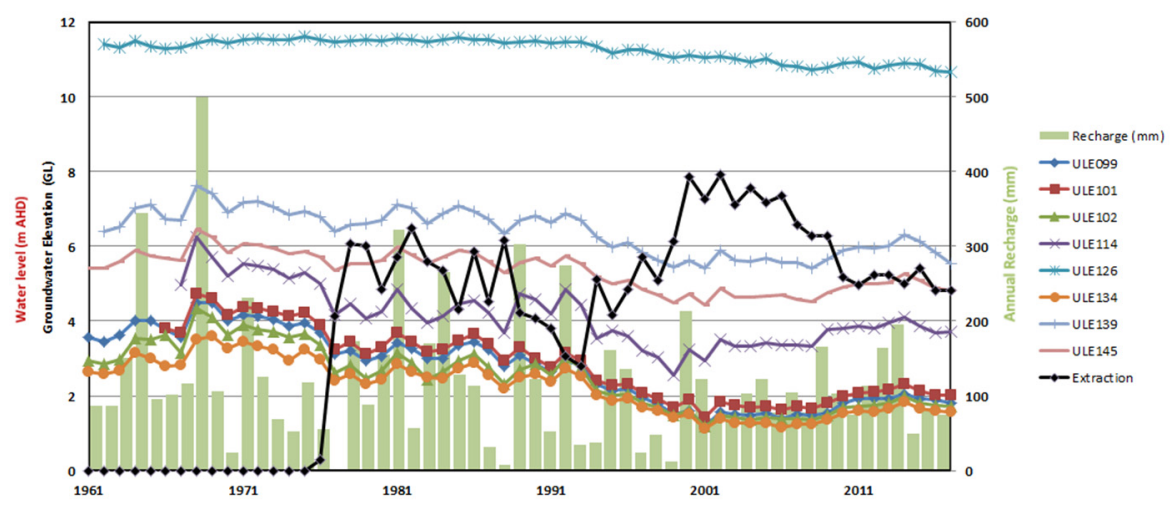

Figure 3. Groundwater extraction, recharge and long-term observed bore hydrographs, 1961-2017

Despite increased extractions, Uley South basin, water levels have gradually increased from 1999 to 2014 in all long-term observed monitoring wells within the basin due to above average (exceeding long-term recharge of $122 \mathrm{~mm}$ ) recharge received in 2000, 2009, 2013 and 2014 (Figure 3). Since 2014, the basin received below average recharge; $49 \mathrm{~mm}$ in 2015, 84mm in 2016 and $75 \mathrm{~mm}$ 2017. As a result, water levels in the central basin, where the majority of production bores are clustered, declined by $0.6 \mathrm{~m}$ (Figure 3) from 2014. Elsewhere in the basin, the long-term observed monitoring wells show $0.4 \mathrm{~m}$ decline compared to the 2014 water level. Three consecutive low recharge years occurred previously in the 1997-1999 period and water levels dropped to the historically lowest recorded levels (Figure 3). Since 2010, groundwater extraction from the basin is relatively constant and remains around $5 \times 10^{6} \mathrm{~m}^{3}$ per year (approximately $70 \%$ of annual allocation).

\subsection{Assessing the Stress Ratings of the Aquifer}

Water Levels: Groundwater development inevitably causes lowering of the watertable. Observation of long-term water levels (Figure 3) show that, water levels have stabilized approximately $0.6 \mathrm{~m}$ to $1.8 \mathrm{~m}$ below the pre- 
development water levels. However, some short- to medium term decline (5-10\%) of saturated thickness with recovery is observed. Thus a rating of 5 was assigned for the water levels criterion (Table 1).

Pumping: Current groundwater extraction from the basin is about $5 \times 10^{6} \mathrm{~m}^{3}$ per year, which is about $42 \%$ of the average annual recharge $(113.5 \mathrm{~mm})$ over the $1976-2017$ period, and $43 \%$ of the previous 10 year average annual recharge $(110 \mathrm{~mm})$. Therefore, rating of 5 was assigned to pumping (Table 1).

Recharge: Declining trends of recharge have been observed since 1992. The recharge reduction is considered to be climate driven and over the last 10 years, average annual recharge is $110 \mathrm{~mm}$; a $9.8 \%$ reduction from long-term average annual recharge $(122 \mathrm{~mm})$. Due to the prevailing drought condition during 2015-2017 period, average annual recharge received to the basin was $69 \mathrm{~mm}$. Rating for recharge was taken as 3 for declining long-term recharge with $<5$ year recovery period.

Land use threat: The basin is a protected water reserve and therefore rating for land use was taken as 1.

Saline Water Intrusion and Water Quality: The basin wide water quality was assessed taking salinity profiles of all monitoring wells and analyzing long-term salinity measurements of the town water supply (TWS) wells (Figure 4). The judgement is based on actual salinity variation across the basin.

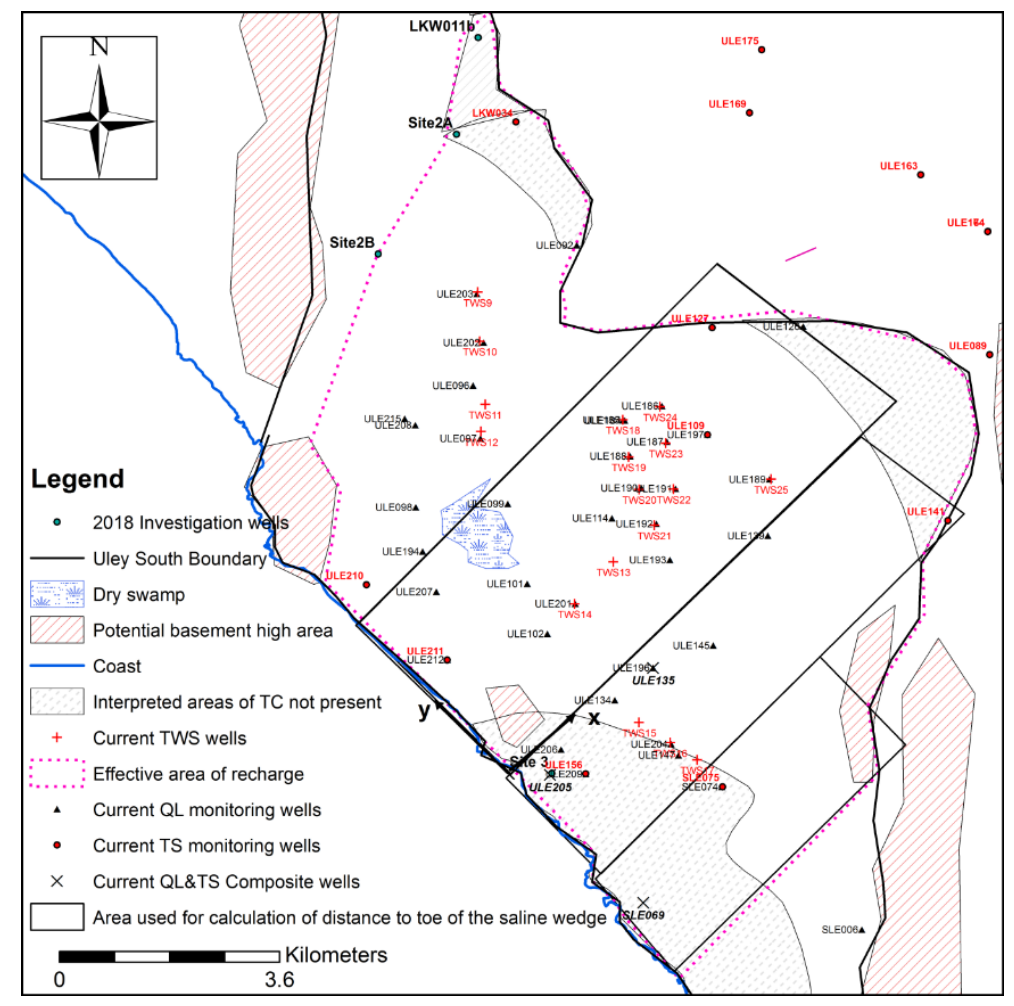

Figure 4. Location of coastal and inland salinity monitoring wells with respect to town water supply (TWS) production wells. Axes $\mathrm{x}$ and $\mathrm{y}$ directions are as shown in the Figure

Water Quality-Inland Salinity: The TS layer is absent in southern part of the adjoining Uley East (Figure 1a); as well as the presence of basement rock high areas (Somaratne et al., 2018) in south-east boundary of Uley South (Figure 4). It is only in northern half of the Uley South basin, the TS layer continues from Uley South boundary to Uley Wanilla and Big Swamp area (Somaratne et al., 2018). Therefore, inter-aquifer leakage from TS to QL is only received to the northern half of the basin (Somaratne et al., 2018). The Tertiary Sand aquifer monitoring wells, ULE163, ULE164, and ULE169 (Figure 4) are located about 2.5km up-gradient of the northern boundary of Uley South. EC values of these wells range from $1050 \mu \mathrm{S} . \mathrm{cm}^{-1}$ to $1900 \mu \mathrm{S} . \mathrm{cm}^{-1}$ (Figure 5). In general, EC of brackish water increases with the depth. Higher EC water of TS aquifer originates from the Big Swamp area (Somaratne et al., 2018). 

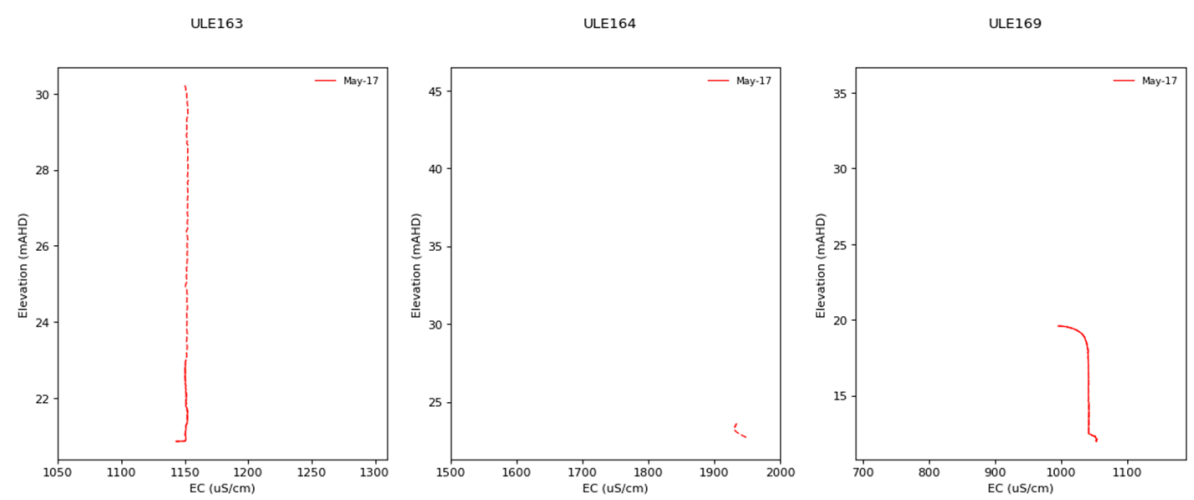

Figure 5. EC values of TS water up-gradient to the Uley South northern boundary

As a result of TS aquifer water entering QL aquifer, EC of the QL water in the northern part of the Uley South basin has increased (Somaratne et al., 2018). This is shown in QL monitoring well ULE197 where EC is about $1200-1400 \mu{\mathrm{S} . \mathrm{cm}^{-1}}$; the same as the adjacent TS monitoring well ULE109 located at the same site (Figure 6). In contrast, $\mathrm{EC}$ of QL water in southern part of the basin is about $850 \mu{\mathrm{S} . \mathrm{cm}^{-1}}$ as evidenced in QL aquifer monitoring well ULE139 (Figure 6).
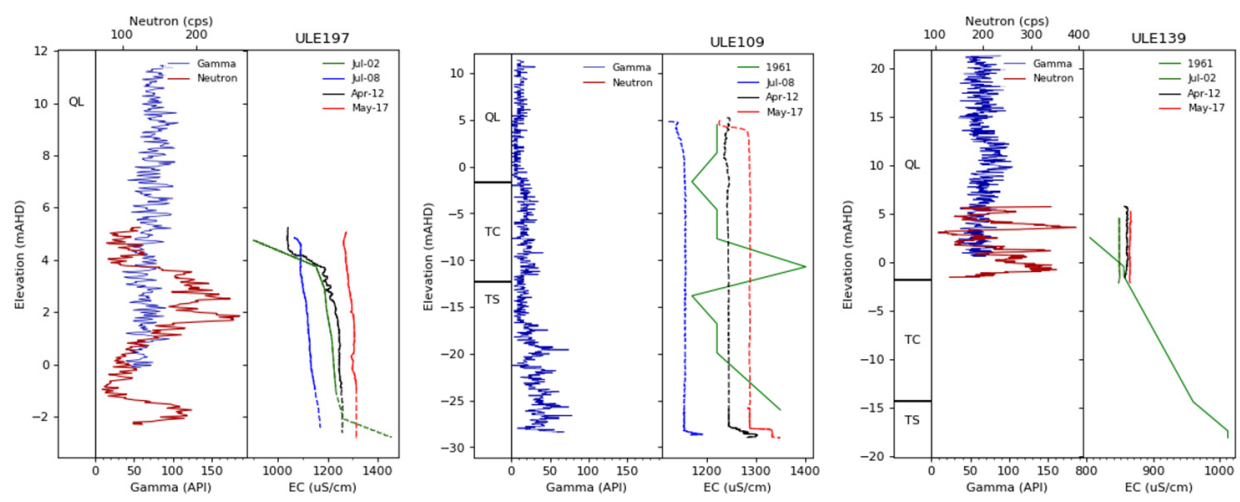

Figure 6. Gamma, Neutron and EC profiles for ULE197 (QL), ULE109 (TS) and ULE139 (QL) monitoring wells. Solid line indicates the EC of production zone (Somaratne et al., 2018)

Some of the town water supply wells located closer to the northern boundary of Uley South basin shows an increase in EC. These wells are: TWS 19 (replacement of TWS 2), TWS 20 (replacement of TWS 3); TWS 9 and TWS 12. EC of TWS $2 \& 19$ is presented in Figure 7 (a), and TWS $3 \& 20$ is presented in Figure 7(b). EC of nearby (within 60m) QL aquifer monitoring wells, ULE188 and ULE190 are given in Figure 8 (a) and 8(b).

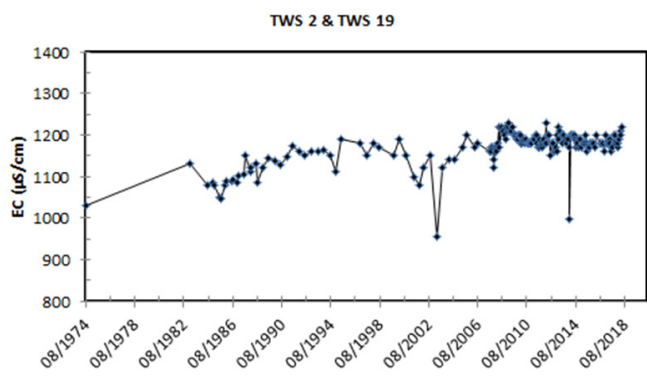

(a)

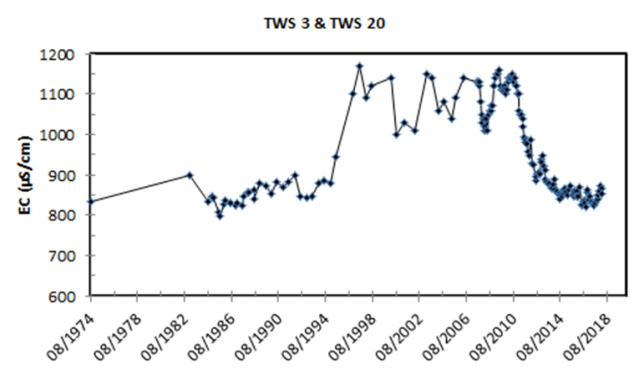

(b)

Figure 7. EC variations in TWS 2 \& TWS19 (TWS 2 replaced by TWS 19 in 2016), and TWS 3 \& TWS 20 (TWS 3 replaced by TWS 20 in 2016) 
ULE188

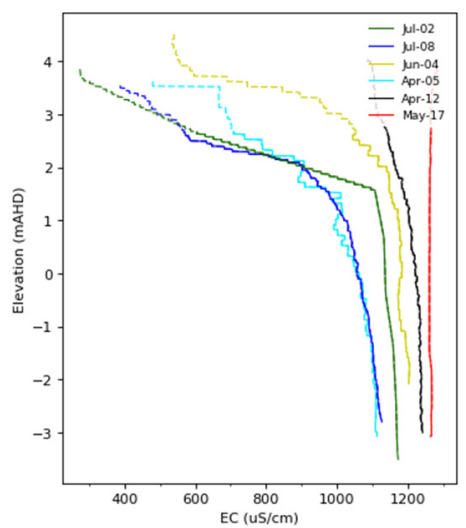

(a)

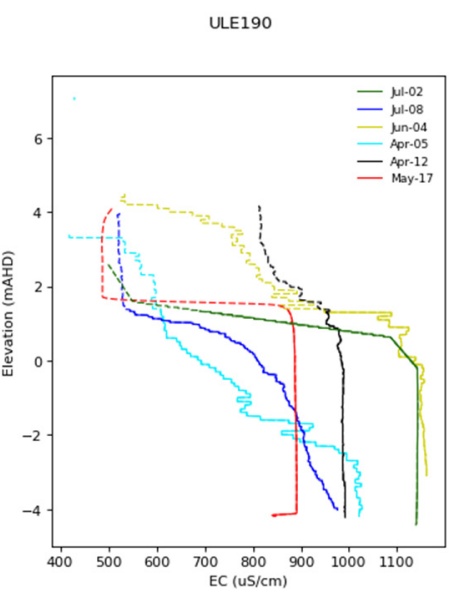

(b)

Figure 8. EC variations in (a) ULE188 (near TWS 19) and (b) ULE190 (near TWS 20)

Higher EC (900-1200 $\left.\mathrm{MS} . \mathrm{cm}^{-1}\right)$ water at the bottom part of the aquifer as reflected in ULE188 and ULE190 wells is the result of TS water leakage into the QL aquifer. Locally recharged, slightly lower EC $\left(600-800 \mu \mathrm{S} . \mathrm{cm}^{-1}\right) \mathrm{water}$ can be found in the upper part of the aquifer. Current EC values of TWS $2 \& 19$ (Figure 7a) are comparable with an EC profile obtained in May 2017 in ULE188 (EC of about $1200 \mu \mathrm{S} / \mathrm{cm}$ ). EC of TWS 3 (Figure 7b) increased to $1100 \mu \mathrm{S} . \mathrm{cm}^{-1}$ during the $1998-2008$ periods. This increase is in line with an increase in pumping during the same period to support the higher demand (Figure 3). A subsequent reduction in EC corresponds to reduced pumping effort from the well. An increasing trend in EC is found in TWS 9 (from 2008-current) and TWS 12 (from 2004 current) (Figure 9). EC profiles obtained in May 2017 from ULE203 (near TWS 9) and ULE097 (near TWS 12) are given in Figure 10. EC values obtained from profiling using a sonde are in good agreement with current EC values of corresponding TWS wells.
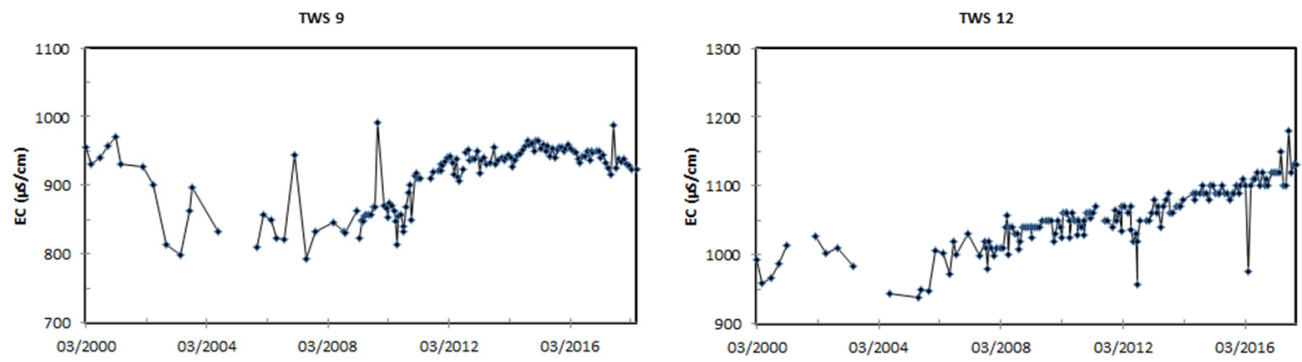

Figure 9. EC variations in TWS 9 and TWS 12

ULE203

ULE097

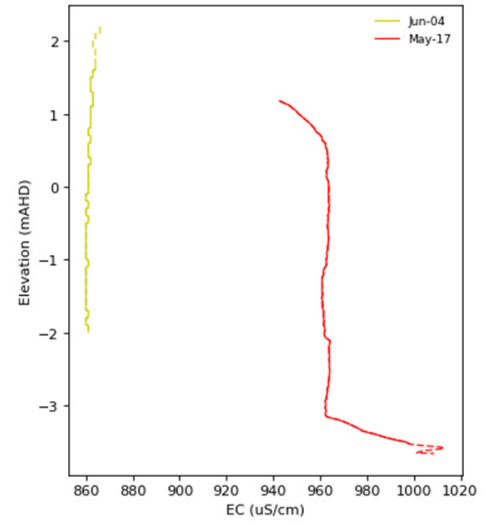

(a)

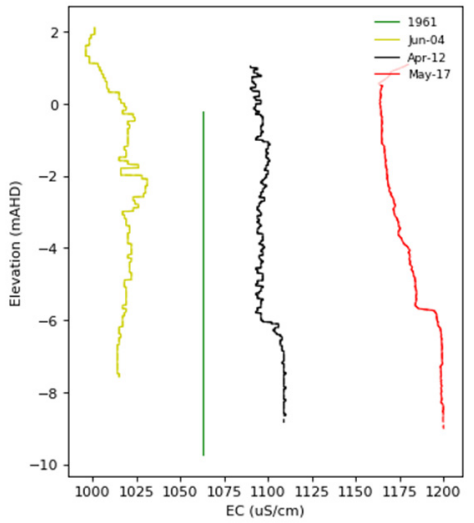

(b)

Figure 10. EC variations in ULE203 (near TWS 9) and ULE097 (near TWS 12) 
The EC contrast from the northern and southern part of the basin is used to calculate the volume of TS water entering the QL aquifer. The long term average recharge, $122 \mathrm{~mm}$, distributed to the northern part of the basin $\left(60 \mathrm{~km}^{2}\right)$ and the southern part $\left(53 \mathrm{~km}^{2}\right)$ resulted in $7.3 \times 10^{6} \mathrm{~m}^{3}$ of recharge in northern part and $6.4 \times 10^{6} \mathrm{~m}^{3}$ in the southern part. Average salinity of town water supply wells in the northern part is $553.5 \mathrm{mg} . \mathrm{L}^{-1}$ (TWS 9, TWS10, TWS11, TWS 12, TWS 18, TWS 19, TWS 20, TWS 22, TWS 23 and TWS 24) and that of the southern part is 477.7mg.L $\mathrm{L}^{-1}$ (TWS 13, TWS 14, TWS 15, TWS 16, TWS 17, TWS 21 and TWS 25). The average salinity of TS monitoring wells ULE163, ULE164 and ULE169, north of Uley South basin is 710mg.L-1. This is taken as the TS water salinity that enters the QL aquifer. Using the salinity balance of the northern part of the basin, a volume of TS water that enters QL aquifer is calculated as $3.5 \times 10^{6} \mathrm{~m}^{3}$.

Based on above data, rating of 3 was assigned for, water quality criterion.

\subsection{Sea Water Intrusion}

Coastal salinity of the basin was assessed in the central area, directly down gradient to the main wellfield, where TWS13-14 and TWS18-25 production wells are located (Figure 4). Using analytical model, the distance from the coastline to the toe of the saline wedge was calculated and presented in Figure 11.

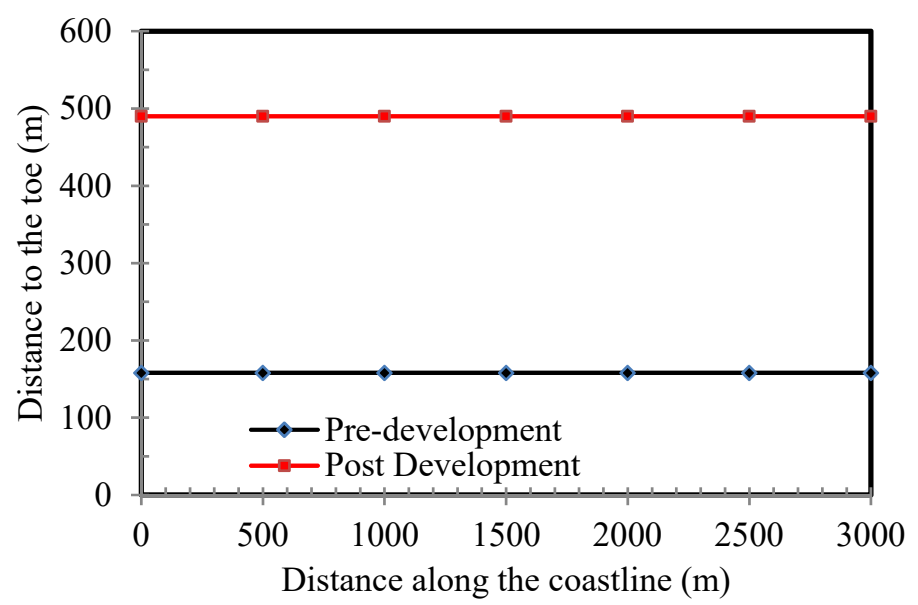

Figure 11. Preliminary results of calculated distance to the toe of the saline wedge; pre-(1975) and postdevelopment (2017) (hydraulic conductivity of $140 \mathrm{~m}^{-\mathrm{d}^{-1}}$ was taken for the QL aquifer)

The calculated contemporary coastal discharge using Equation (16) is $2.2 \mathrm{~m}^{2} \cdot \mathrm{d}^{-1}$, which produce an annual discharge of $10.8 \times 10^{6} \mathrm{~m}^{3}$ along the Uley South effective coastline $(13.5 \mathrm{~km})$. The sum of annual discharge and current groundwater pumping $\left(5 \times 10^{6} \mathrm{~m}^{3}\right)$ equates to $15.8 \times 10^{6} \mathrm{~m}^{3}$ per year; which is higher than the average annual recharge (1976-2017) of $12.8 \times 10^{6} \mathrm{~m}^{3}$. The imbalance of about $3 \times 10^{6} \mathrm{~m}^{3}$ may be the net contribution of TS aquifer leakage to the QL aquifer from the northern boundary. The discrepancy of $0.5 \times 10^{6} \mathrm{~m}^{3}$ may be due to number of approximation used in the calculations. The water balance components can be refined by using a calibrated transient numerical groundwater model. The calculated distance to the toe of the saline wedge (Figure 11) shows that the toe of the wedge has moved from $158 \mathrm{~m}$ (1975) to 490m (2017). ULE212 is a coastal salinity monitoring well, and is located $540 \mathrm{~m}$ from the coastline. Vertical profiles of EC in ULE212 (Figure 12) is an indication that the saline wedge has not influenced the well at $-12 \mathrm{mAHD}$. This is due to the base of the QL layer at this location is at $-23 \mathrm{~m}$ AHD. ULE210 and ULE211 (Figure 6) are Tertiary Sand aquifer monitoring wells and the EC values indicate transition zone of the saline wedge has reached these wells (increasing EC with depth).

TWS15-TWS17, are located at the margin of the Tertiary Clay absent area. Near coast EC variations are given in Figure 13 for both ULE205 and the adjacent well labelled as 'Site 3'. The TC layer is absent in ULE205 area and the well is completed in both QL and TS aquifers with a production zone from 36m AHD to -30m AHD. The QL base is at -23m AHD (Figure 13a). EC stratification in QL aquifer in ULE205 is due both to the transition zone of the saline wedge as well as saline water movement along the long-screen wells. 

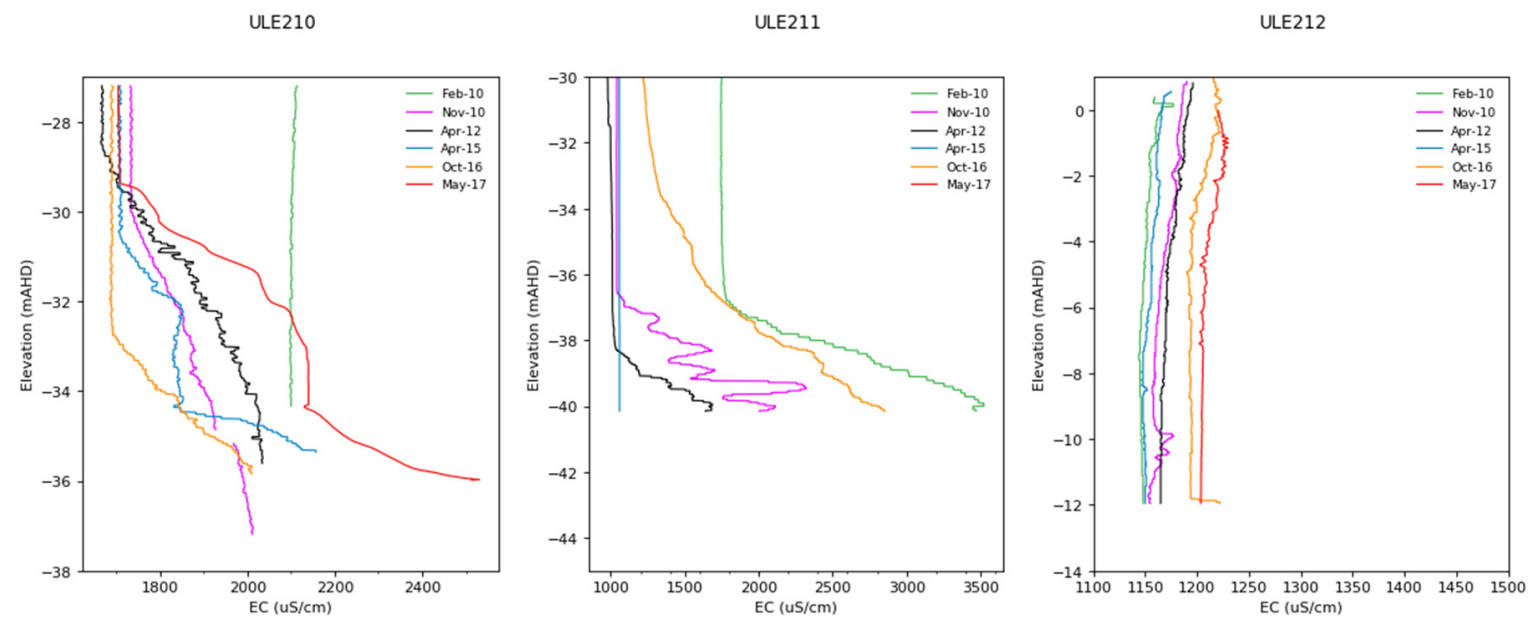

Figure 12. EC profile dynamics in QL and TS aquifer (solid line indicates the production zone of the well). ULE2 10 is $550 \mathrm{~m}$ and ULE2 11 about $540 \mathrm{~m}$ from the coast. QL aquifer monitoring well ULE212 is at $540 \mathrm{~m}$ from the coast (at the same location as ULE211)

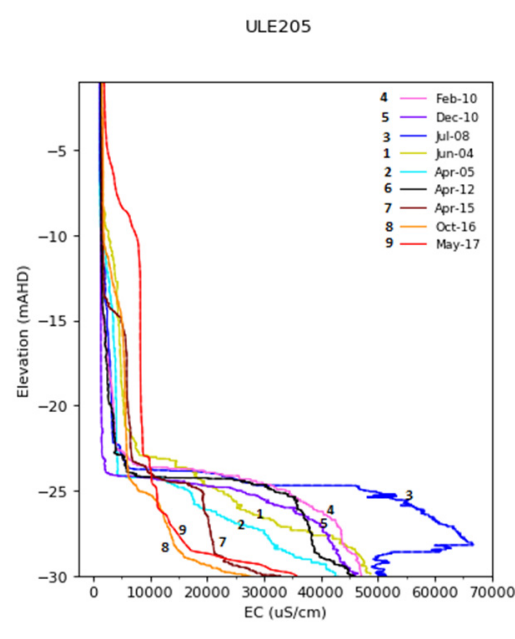

(a)

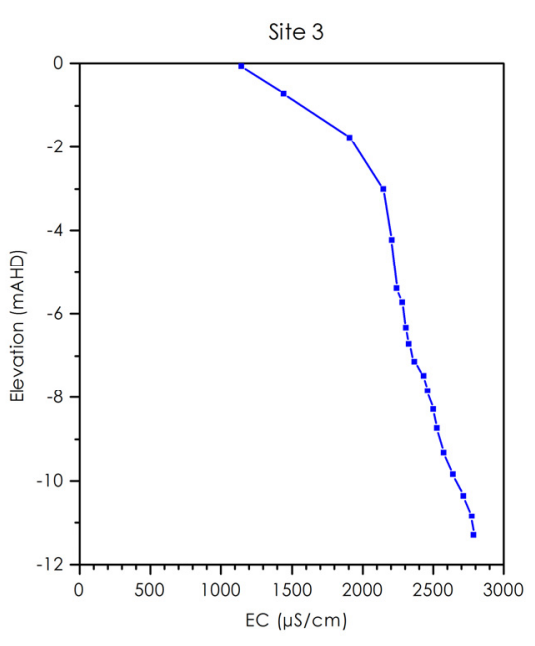

(b)

Figure 13. EC profile s of ULE205 - a composite well completed in both QL and TS aquifers and new QL aquifer monitoring well at Site 3 (Figure 4). The wells are located at $480 \mathrm{~m}$ from the coastline

The new well, Site 3, (Figure 13b) completed at $-12 \mathrm{~m}$ AHD (11m above the QL base which is similar to the ULE212) has lower EC $\left(2500 \mu \mathrm{S} . \mathrm{cm}^{-1}\right)$ compared to the same elevation in ULE205 $\left(10,000 \mu \mathrm{S} . \mathrm{cm}^{-1}\right)$. This illustrates the upward movement of salinity in long-screened wells (in ULE205). EC of the new well at Site 3 is increasing with depth. When compared with ULE212 in Figure 12 (where EC at $-12 \mathrm{~m}$ AHD is $1200 \mu \mathrm{S} . \mathrm{cm}^{-1}$ ), the indication is that the transition zone of the saline wedge in the QL has reached the well at Site 3 (480m from coast). EC profiles of wells located further inland from the coastline are given in Figure 14. The wells ULE156 (TS) and ULE209 (QL) are located at the same site at $950 \mathrm{~m}$ from the coastline. The increase in EC within the saline wedge has passed 480m from the coast (Site 3 well near ULE205) and has not reached ULE206 and ULE209 wells located at $880 \mathrm{~m}$ and $950 \mathrm{~m}$ from the coastline. However, an increase in EC in ULE156, Tertiary Sand well near ULE209 shows that the transition zone of the saline wedge has moved to this location in the TS aquifer.

The SLE069 well is the closest to the coastline (Figure 4) located at a distance of 400m. The freshwater-saltwater interface and transition zone starts at a shallow depth at about $-15 \mathrm{~m}$ AHD elevations. The dynamic behavior of the EC profiles is considered to be the response to the variation of water levels in both QL and TS aquifers. SLE075 (TS) and SLE074 (QL) monitoring wells located 2550m inland, show similar EC values (Figure 15). Lithology of 
SLE069 indicates TC is absent in the area and the QL and TS aquifer interface is at -20m AHD where EC at the interface is equivalent to seawater. The production zone of the well is from $13.6 \mathrm{~m}$ AHD to $-22.4 \mathrm{~m}$ AHD. This indicates that the saline wedge of the interface has moved inland. SLE069 well is cased to 14m AHD and the composite water level is at $0.28 \mathrm{~m}$ AHD. A significant variation of EC starts below $-10 \mathrm{~m}$ AHD within the QL aquifer. The SLE075 well is constructed to reach $-39.7 \mathrm{~m}$ AHD elevation with the production zone at -35.2 to $39.7 \mathrm{~m}$ AHD. The EC at this elevation $\left(1050 \mu \mathrm{S} . \mathrm{cm}^{-1}\right)$ is equivalent to the QL well, SLE074, at the same location with production zone set at -17 to $-33.6 \mathrm{~m}$ AHD elevation. Despite the elevation of production zone being twice as that of the SLE069 well, saline wedge in the TS aquifer has not reached to $2550 \mathrm{~m}$ from the coast.

ULE156

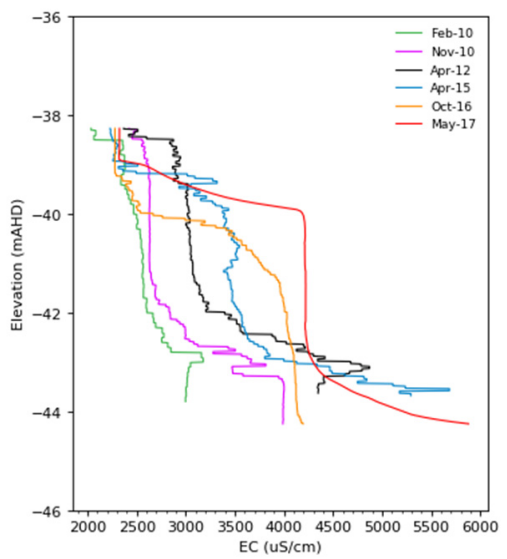

ULE209

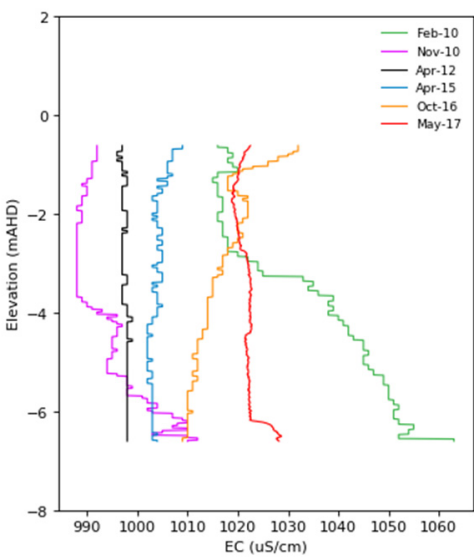

ULE206

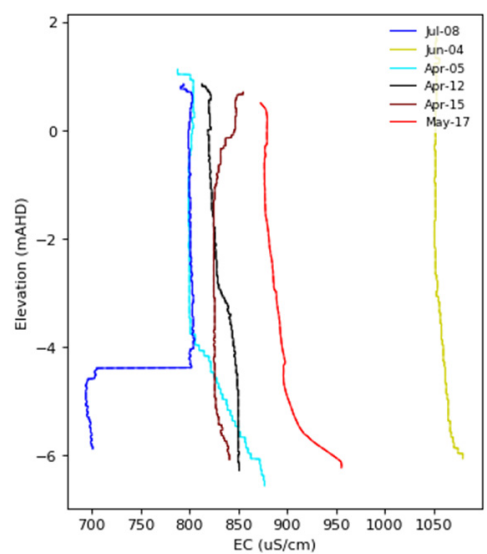

Figure 14. EC profiles in Zone B (solid line indicates the production zone EC; ULE156 is TS well and ULE209 is a QL well from 950m from the coast. ULE206 is a QL well from 880m from the coast)
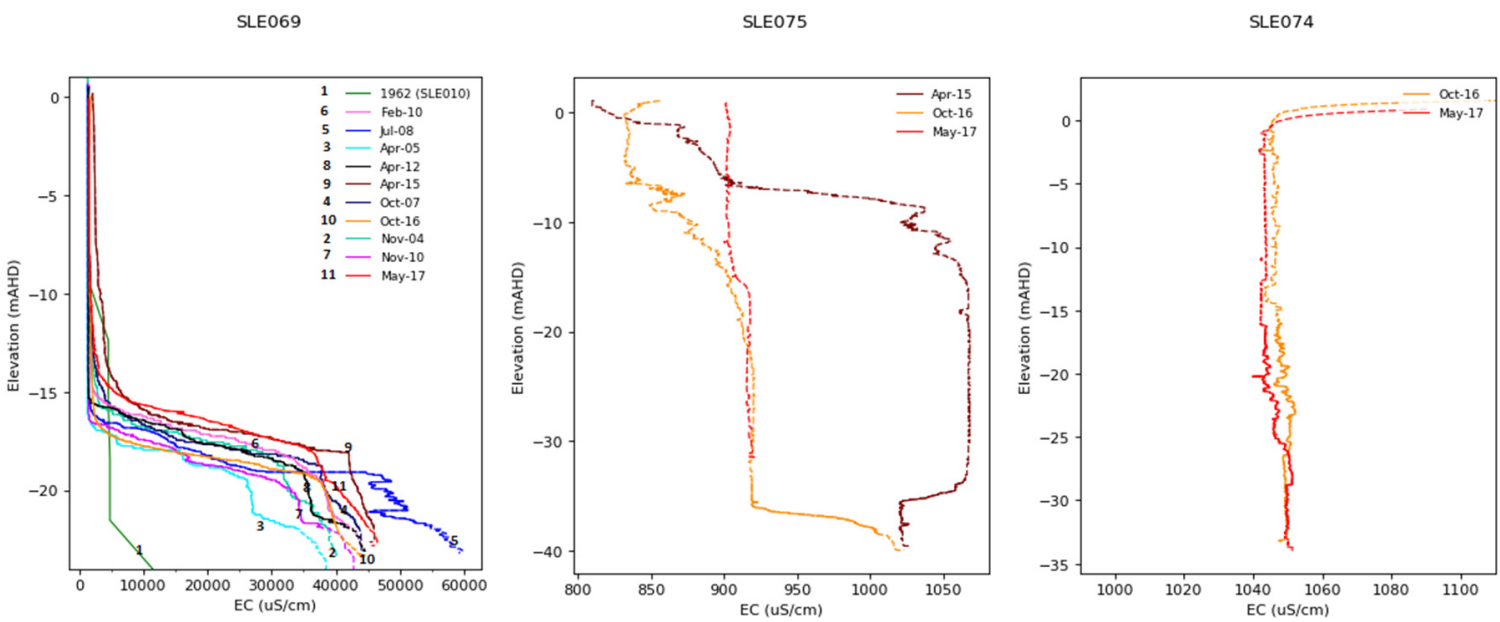

Figure 15. EC profile dynamics of SLE069, SLE075 and SLE074 wells (solid line indicates the production zone EC; SLE069 is a composite well, SLE075 is a TS well and SLE074 is a QL well)

Based on above data, rating of 3 (Table 1) was assigned to the saline water intrusion criterion.

\subsection{Aquifer Stress Index (ASI) for Uley South Basin and Management Options}

Aquifer stress level was assessed using equation (1) based on ratings for water levels (5), water quality (3), pumping (5), saline water intrusion (3), recharge (3) and land use (1), and corresponding weightings from Table 5. The ASI was calculated at 3.8 for the Uley South aquifer, which indicates that the aquifer is showing to starts moderate (3-5) stress. As the water level recovers, water quality will naturally improves. For this to happens, 
several years of average or above average recharge is required. At present, in 2018, (August) winter recharge received to the basin is well below the average $(53 \mathrm{~mm})$ and the prospect is a $4^{\text {th }}$ drought year.

In 2018, four investigation wells were drilled in Uley South, at LKW011b, Site 2a, Site2b and Site 3. The purpose of LKW011b, Site2a and Site2b is to determine whether QL is wet or dry. Drilling of Site 2a, and Site 2b proved the presence of dry QL. This reduces the effective recharge area of the QL aquifer, that is recharging the wellfield. Ignoring the northern and southern tips of the basin, 'effective recharge area' (Figure 4) to the wellfields was determined to be $87 \mathrm{~km}^{2}$. Considering average annual recharge over the last 10 years is $110 \mathrm{~mm}$, average annual recharge volume to the effective recharge area is obtained at $9.57 \times 10^{6} \mathrm{~m}^{3}$. If $40 \%$ of the average annual recharge is to be extracted, sustainable yield from the basin should be $3.8 \times 10^{6} \mathrm{~m}^{3}$ which is $76 \%$ of current pumping, and $54 \%$ of the current allocation. Thus, under the current climatic regime, reduced abstraction is required in order to achieve sustainability.

For comparison, the ASI assessment methodology was applied to Coffin Bay, Uley Wanilla and Lincoln Basin aquifers. In Coffin Bay, a reliable data set is currently available from 1986. Stable water levels have been found in the wellfield area over the last 31 years. Current groundwater extraction is about $0.116 \times 10^{6} \mathrm{~m}^{3}$ per year. The current wellfield is at yield capacity and the estimated ASI for the Coffin Bay is 3, indicating low stress level. Uley Wanilla basin's sustainable extraction has been back calculated at $0.6 \times 10^{6} \mathrm{~m}^{3}$ per year, based on $40 \%$ of the long term average recharge rate of $40 \mathrm{~mm}$ per year. In contrast, and as a result of high demands and limited knowledge of the groundwater system, extractions generally exceeded the sustainable limit between 1950 and 1999, with pumped volumes exceeding $2 \times 10^{6} \mathrm{~m}^{3}$ per year from $1958-1963$ and again in 1976/77. Water levels in the basin are continuously declining (up to $7 \mathrm{~m}$ ) since the inception of the wellfield. A slight stabilization in 2010 corresponds with high recharge in 2010 and low groundwater extraction. Estimated ASI for the Uley Wanilla Basin is 5.7, indicating that the basin is highly stressed.

With demand increasing on Eyre Peninsula since the 1950's it became necessary to develop an additional water resource to supplement Uley Wanilla Basin. In 1959-60 the coastal aquifers of Lincoln Basin were investigated as the source of water supply to Port Lincoln. Based on pump tests conducted during development, it had been concluded that 'a large body of water was located in three areas in the Lincoln Basin' and recommended developing a supply capable of $2 \times 10^{6} \mathrm{~m}^{3}$ per year. Lincoln Basin is surrounded by sea, with the watertable just above sea level and highly saline groundwater sitting at depth in the aquifer. Pumping from the basin commenced in 1962 and over the next 15 years averaged $2.2 \times 10^{6} \mathrm{~m}^{3}$ per year, culminating in 1976 with $3.4 \times 10^{6} \mathrm{~m}^{3}$ per year extracted. Total recharge was back calculated to be $1.6 \times 10^{6} \mathrm{~m}^{3}$ per year (Somaratne \& Ashman, 2018). Over extraction made the basin prone to salinization from lateral and upward movement of saline water. As a result, in 1976 the basin became too saline and pumping was drastically reduced and eventually ceased (Somaratne \& Ashman, 2018). The estimated ASI for the Lincoln Basin is 6, indicating high stress levels.

\section{Conclusions}

All aquifers are stressed seasonally but long-term stress is a concern for sustainability and water security. This paper introduces the Aquifer Stress Index (ASI) based on six measurable criteria: water levels, water quality, groundwater pumping, saline water intrusion, recharge and land use threat. The study groundwater basin, Uley South aquifer, received below average recharge over the last three years $(49 \mathrm{~mm}$ in $2015,84 \mathrm{~mm}$ in 2016 and $75 \mathrm{~mm}$ in 2017) compared to the long-term (1961-2017) annual average recharge of $122 \mathrm{~mm}$ per year. Groundwater pumping continued at about $5 \times 10^{6} \mathrm{~m}^{3}$ per year over the last eight years. This combination of recharge and pumping has resulted in Uley South basin's water levels declining by $0.4-0.6 \mathrm{~m}$ and salinity increasing by about $30 \mathrm{mg} . \mathrm{L}^{-1}$. Under the current climatic regime, a reduced annual abstraction of $3.8 \times 10^{6} \mathrm{~m}^{3}$, (which is $40 \%$ of average annual recharge over last 10 years to effective recharge area) has been suggested as the safe yield.

\section{Acknowledgment}

This study was funded by the South Australian Water Corporation under resource assessment and water security planning in Southern Eyre Peninsula. Sumudu Narayana, Brooke Swaffer and Glyn Ashman are thanked for early review of the paper. The editor and anonymous reviewers are thanked for their useful comments.

\section{Conflict of interests}

The author declares that there is no conflict of interests regarding the publication of this paper.

\section{References}

Agarwal, E., Agarwal, R., Garg, R. D., \& Garg, P. K. (2003). Delineation of groundwater potential zones: An AHP/ANP approach. $J$. Earth Syst. Sci., 122(3), 887-898. 
Ahner, B. (n. d.). Assessing Groundwater Stress, An approach of measuring groundwater stress based on subnational statistical data, International Groundwater Resources Assessment Centre (undated). Retrieved Decemebr 7, 2018, from https://www.un-igrac.org/file/1355/download?token=W-h03vBK

Aller, L., Bennet, T., Lehr, J. H., \& Petty, R. J. (1987). DRASTIC: A standardized system for evaluating groundwater pollution potential using hydrogeologic settings. USEPA, Robert S. Kerr Environmental Research Laboratory, Ada, OK. EPA/600/2 85/018.

Al-Zubi, Y. A. (2009). Application of Analytical Hierarchy Process for the evaluation of climate change impact on ecohydrology: The case of Azraq Basin in Jordan. Journal of Applied Sciences, 9(1), 135-141.

Anagnostopoulos, K. P., Petalas, C., \& Pisinaras, V. (2005). Water resources planning using the AHP and PROMETHEE Multicriteria methods: The case of Nestor river-Greece. The 7th Balkan Conference on Operational Research, Constanta, Romania.

Ashraf, B., AghaKouchak, A., Alizadeh, A., Baygi, M. M., Moftakhari, H. R., Mirchi, A., Anjileli, H., \& Madani, K. (2017). Quantifying anthropogenic stress on groundwater resources. Scientific Reports, 7, 12910.

Barnett, S. R. (1978). Eyre Peninsula Groundwater Survey Uley South Basin, Progress Report 5-Water balance and safe Yield. Dept. Mines and Energy, S.Aust., Report Book No. 78/22, 1978.

Blachowski, J. (2015). Methodology for assessment of the accessibility of a brown coal deposit with Analytical Hierarchy Process and Weighted Linear Combination. Environ. Earth Sci., 74, 4119-4131.

Cambrainha, G. M., \& Fontana, M. E. (2018). A multi-criteria decision making approach to balance water supply demand strategies in water supply systems. Production, 28, e20170062.

Castagna, M., Bellin, A., \& Chiogna, G. (2015). Uncertainty estimation and evaluation of shallow aquifers' exploitability: The case study of the Adige Valley aquifer (Italy). Water 2015, 7, 3367-3395.

Cheng, A. H. D., \& Ouazar, D. (1999). Chapter 6: Analytical Solutions. In J. Bear, H. D. Cheng, S. Sorek, D. Ouazar, \& I. Herrara (Eds.), Groundwater Problems in Coastal Areas, Studies and Reports in Hydrology. United Nations Educational, Scientific and Cultural Organization, Paris, France.

Custodio, E. (1987). Salt-fresh water interrelationships under natural conditions. Chapter 3. In E. E. Custodio \& G. A. Bruggeman (Eds.), Groundwater Problems in Coastal Areas, Studies and Reports in Hydrology. United Nations Educational, Scientific and Cultural Organization, Paris, France.

Eldardiry, H., Habib, E., \& Borok, D. (2016). Small-scale catchment analysis of water stress in wet regions of the U.S.: An example from Louisiana. Environ. Res. Lett., 11, 124031.

Evans, S. L. (1997). Estimating long-term recharge to thin, unconfined carbonate aquifers using conventional and environmental isotopes techniques: Eyre Peninsula. South Australia., Masters Thesis, Flinders University of South Australia (unpublished).

Felisa, G., Ciriello, V., \& Federico, V. D. (2013). Saltwater intrusion in coastal aquifers: A primary case study along the Adriatic coast investigated within a probabilistic framework. Water 2013, (5), 1830-1847.

Franek, J., \& Kresta, A. (2014). Judgement scales and consistency measure in AHP. Procedia Economics and Finance, 12, 164-173. Enterprise and the Competitive Environment 2014 Conference, March 2014, Czech Republic.

Gleeson, T., \& Wada, Y. (2013). Assessing regional groundwater stress for nations using multiple data sources with the groundwater footprint. Environ. Res. Lett., 8(2013).

Gleeson, T., Wada, Y., Bierkens, M. F. P., \& van Beek, L. P. H. (2012). Water balance of global aquifers revealed by groundwater foot print. Nature, 488, 197.

Harrington, N., Zulfic, D., \& Wohling, D. (2006). Uley basin groundwater modelling project. Volume 1: Project overview and conceptual model development, DWLBC Report 2006/01, Government of South Australia.

Hashimoto, T., Stedinger, J. R., \& Loucks, D. P. (1982). Reliability, resiliency and vulnerability criteria for water resources planning. Water Resour. Res., 18, 14-21.

Healy, R. W., \& Cook, P. G. (2002). Using groundwater levels to estimate recharge. Hydrogeology Journal, 10, 91-109.

Huang, Y., Zuo, R., Li, J., Wu, J., Zhai, Y., \& Teng, Y. (2018). The spatial and temporal variability of groundwater vulnerability and human health risk in the Limin District, Harbin, China. Water 2018, 10, 686. 
Hunter, C., Gironas, J., Bolster, D., \& Karavitis, C.A. (2015). A dynamic, multivariate sustainability measure for robust analysis of water management under climate and demand uncertainty in an arid environment. Water $2015,7,5928-5958$.

Johns, R. K. (1961). Geology and mineral resources of Southern Eyre Peninsula. Geological Survey of South Australia, 37.

Kalf, F. R. P., \& Wooley, D. R. (2005). Applicability and methodology of sustainable yield determination in groundwater systems. Hydrogeology Journal, 13(1), 295-312.

Kumar, A., \& Krishna, A. P. (2016). Assessment of groundwater potential zones in coal mining impacted hardrock terrain of India by integrating geospatial and analytical hierarchy process (AHP) approach. Geocarto International.

Kundzewicz, Z. W. (2009). Water resources for sustainable development. Hydrological Science Journal, 42(4), 467-480.

Liu, M., Wei, J., Wang, G., \& Wang, F. (2017). Water resources assessment and risk early warning - a case of Hebei Province China. Ecological Indicators, 73, 358-368.

Molina, J. L., Martos-Rosillo, S., Martin-Montanes, C., \& Pierce, S. (2018). The social sustainable aquifer yield: An indicator for the analysis and assessment of the integrated aquifers management. Water Resources Management, 26, 2951.

Montoglou, A. (2003). Pumping management of coastal aquifers using models of salt water intrusion. Water Resources Research, 39(12).

Morton, W., \& Steel, T. M. (1968). Eyre Peninsula Groundwater study Uley South basin, Progress report No.1 Aquifer evaluation. South Australian Dept. Mines, report Book 66/45.

Naderi, M. N. N., Kermani, M. R. H., \& Barani, G. A. (2013). Possibility of groundwater operation in coastal aquifers for prevention of seawater intrusion. Bulletin of Environment, Pharmacology and Life Sciences, 2(11), 30-38.

Painter, J. A. C. (1969). Eyre Peninsula Groundwater Study Uley South basin, Progress Report No. 2-Aquifer evaluation. South Australian Dept. Mines, Report Book 69/77.

Pandey, V. P., Shresta, S., Chapagain, S. K., \& Kazama, F. (2011). A framework for measuring groundwater sustainability. Environ. Sci. Policy, 14, 396.

Richey, S. R., Thomas, B. F., Lo, M., Reager, J. T., Famiglietti, J. S., Voss, K., Swenson, S., \& Rodell, M. (2015). Quantifying renewable groundwater stress with GRACE. Water Resour. Res., 51, 5217-5238.

Russo, T., Alfredo, K., \& Fisher, J. (2014). Sustainable water management in urban, agricultural, and natural systems. Water 2014, 6, 3934-3956.

Saaty, T. L. (1977). A scaling method for priorities in hierarchical structures. Journal of Mathematical Psychology, $15,57-68$.

Saaty, T. L. (1980). The Analytic Hierarchy Process. McGraw-Hill International, New York, NY, U.S.A.

Segnit, R. W. (1942). Final report on the Uley Wanilla fresh water basin, Eyre Peninsula. South Australian Department of Mines, D.M.514/41.

Selby, J. (1974). Uley South Groundwater basin, Proposed use for Port Lincoln water supply. Mineral Resour. Rev., S. Aust., 136, 52-55.

Senet-Aparicio, J., Perez-Sanchez, J., Garcia-Arostegui, J. L., Bielsa-Artero, A., \& Domingo-Pinillos, J. C. (2015). Evaluating groundwater management sustainability under limited data availability in semi-arid zones. Water $2015,7,4305-4322$.

Shabbir, R., \& Ahmad, S. S. (2016). Water resource vulnerability assessment in Rawalpindi and Islamabad, Pakistan using Analytic Hierarchy Process (AHP). Science, 28, 293-299.

Shepherd, R. G. (1963). Report on Underground water Investigations-Sleaford bay-Coffin Bay area. Dept. Mines, unpublished report.

Somaratne, N. (2014). Characteristics of point recharge. Water 2014, 6, 2782-2807.

Somaratne, N. (2015a). Karst Aquifer recharge: A case history of over simplification from the Uley South Basin, South Australia. Water 2015, 7, 464-479. 
Somaratne, N. (2015b). Pitfalls in application of the conventional chloride mass balance (CMB) in karst aquifers and use of the generalized CMB method. Environ Earth Sci.

Somaratne, N., \& Ashman, G. (2018). Analysis of saline intrusion into a coastal aquifer: A case history of legacy issues and challenges to water security. Environment and Natural resources Research, 8(2).

Somaratne, N., Ashman, G., Irvine, M., \& Mann, S. (2018). Geophysical input to improve the conceptual model of the hydrogeological framework of a coastal karstic aquifer: Uley South basin, South Australia. Geosciences 2018, 8, 226.

Strack, O. D. L. (1976). A single-potential solution for regional interface problems in coastal aquifers. Water Resources Research, 12(6), 1165-1174.

Sun, G., McNulty, S. G., Moore-Myers, J. A., \& Cohen, E. C. (2008). Impacts of multiple stresses on water demand and supply across the southeastern United States. J. Am. Water Resour. Assoc., 44, 1441-57.

Tirkey, P., Gorai, A. K., \& Iqbal, J. (2013). AHP-GIS based DRASTIC model for groundwater vulnerability to pollution assessment: A case study of Hazaribag District, Jharkhand, India. International Journal of Environment Protection, 2(3), 20-31.

Triantaphyllou, E. (1997). A sensitivity analysis approach for some deterministic multi-criteria decision making methods. Decision Sciences, 28(1), 151-194.

Triantaphyllou, E., \& Mann, S. H. (1995). Using the Analytic Hierarchy Process for decision making in engineering applications: Some challenges. International Journal of Industrial Engineering: Application and Practice, 2(1), 35-44.

Vaux, H. (2011). Groundwater under stress: The importance of management. Environ Earth Sci., 62, 19-23.

Vrba, J., \& Lipponen, A. (2007). Groundwater resources sustainability indicators. Groundwater Indicator Working Group, (UNESCO, IAEA, IAH), IHP-V1, Series on Groundwater No. 14.

Wang, Z., \& Wu, Q. (2006). Development of groundwater sustainability indicators, Sustainability of Groundwater Resources and its Indicators (Proceeding of symposium S3 held during the Seventh IAHS Scientific Assembly at Foz do Iguacu, Brazil, April 2005). IAHS Publ. 302.

Web, B., Hirata, R., Kruse, E., \& Vrba, J. (2007). Sustainability of groundwater resourcesand its Indicators (Vol. 302). Oxfordshire: IAHS.

White, E. K., Peterson, T. J., Costelloe, J., Western, A. W., \& Carrara, E. (2016). Can we manage groundwater? A method to determine the quantitative testability of groundwater management plans. Water Resources Research, 52, 4863-4882.

Wijitkosum, S. (2018). Fuzzy AHP for drought risk assessment in Lam Ta Kong watershed, the north-eastern region of Thailand. Soil and Water res., 13(1).

Xi, X., \& Poh, K. L. (2014). A novel integrated decision support tool for sustainable water resources management in Singapore: Synergies between System Dynamics and Analytic Hierarchy Process. Water Resour. Manage.

YSI Incorporated. (2014). Environmental Monitoring Systems Operations Manual. Retrieved September 3, 2014, from http//:wenku.baidu.com/view/d785b92058fb770bf78a55ca.html

Zhang, R., Zhang, X., Yang, J., \& Yuan, H. (2013). Wetland ecosystem stability evaluation by using Analytical Hierarchy Process (AHP) approach in Yinchuan Plain, China. Mathematical and Computer Modelling, 57, 366-374.

Zhou, S., Huang, Y., Wei, Y., \& Wang, G. (2015). Socio-hydrological water balance for water allocation between human and environmental purposes in catchments. Hydrol. Earth Scst. Sci., 19, 3715-3726.

Zou, V. H. L. (1999). A study on the approach of establishing indicator system for assessing sustainable development. Environ. Sci. J., 19, 360-365.

\section{Copyrights}

Copyright for this article is retained by the author(s), with first publication rights granted to the journal.

This is an open-access article distributed under the terms and conditions of the Creative Commons Attribution license (http://creativecommons.org/licenses/by/4.0/). 